\title{
Molecular evolution of the Chlamydiaceae
}

\author{
Robin M. Bush ${ }^{1}$ and Karin D. E. Everett ${ }^{2}$ \\ Author for correspondence: Karin D. E. Everett. Tel: +1 706583 0237. Fax: +1 7065425771. \\ e-mail: keverett@calc.vet.uga.edu or kdeeverett@hotmail.com
}

1 Department of Ecology and Evolutionary Biology, University of California, Irvine, CA 92697, USA

2 Department of Medical Microbiology and Parasitology, College of Veterinary Medicine, University of Georgia, Athens, GA 30602, USA

\begin{abstract}
Phylogenetic analyses of surface antigens and other chlamydial proteins were used to reconstruct the evolution of the Chlamydiaceae. Trees for all five coding genes [the major outer-membrane protein (MOMP), GroEL chaperonin, KDO-transferase, small cysteine-rich lipoprotein and 60 kDa cysteine-rich protein] supported the current organization of the family Chlamydiaceae, which is based on ribosomal, biochemical, serological, ecological and DNA-DNA hybridization data. Genetic distances between some species were quite large, so phylogenies were evaluated for robustness by comparing analyses of both nucleotide and protein sequences using a variety of algorithms (neighbour-joining, maximum-likelihood, maximum-parsimony with bootstrapping, and quartet puzzling). Saturation plots identified areas of the trees in which factors other than relatedness may have determined branch attachments. All nine species were clearly differentiated by distinctness ratios calculated for each gene. The distribution of virulence traits such as host and tissue tropism were mapped onto the consensus phylogeny. Closely related species were no more likely to share virulence characters than were more distantly related species. This phylogenetically disjunct distribution of virulence traits could not be explained by lateral transfer of the genes we studied, since we found no evidence for lateral gene transfer above the species level. One interpretation of this observation is that when chlamydiae gain access to a new niche, such as a new host or tissue, significant adaptation ensues and the virulence phenotype of the new species reflects adaptation to its environment more strongly than it reflects its ancestry.
\end{abstract}

Keywords: Chlamydia, Chlamydophila, Chlamydiales, phylogeny, intracellular bacteria

\section{INTRODUCTION}

Bacteria in the family Chlamydiaceae are obligately intracellular parasites that infect a diverse array of vertebrates. Chlamydiae cause a wide variety of health problems, including spontaneous abortion in livestock, systemic disease in birds and both endemic and zoonotic infection of humans (Herring, 1993; Everett \& Andersen, 1997). In humans, chlamydiae are the

This paper is dedicated to the late Jan Ursing, Associate Editor of IJSB, who was extraordinarily helpful with our paper on reclassification of Chlamydiales.

Abbreviations: INDELs, insertions and deletions; LGT, lateral gene transfer; ML, maximum-likelihood; MOMP, major outer-membrane protein; MP, maximum-parsimony; NJ, neighbour-joining; QP, quartet puzzling.

The GenBank accession numbers for the scanned and new data produced in this study are AF269256-AF269282 and AF240773. leading cause of preventable blindness and sexually transmitted disease and have suspected links to cardiovascular disease (Campbell et al., 1998; Schachter, 1999). The evolutionary processes responsible for this diverse array of virulence phenotypes have long been of interest. Previous evolutionary studies of the Chlamydiaceae involved phylogenetic reconstruction using rRNA genes (Fig. 1a) (Everett et al., 1999a) and the gene for the major outer-membrane protein (MOMP) (Fitch et al., 1993). Examinations of chlamydial mechanisms of disease, virulence determinants and genome structure have produced a rich set of sequence data for additional coding genes (reviewed by Stephens, 1999; also Kalman et al., 1999; Read et al., 2000). We have used the available data to study the extent to which the evolutionary history of genes in the family Chlamydiaceae explains the distribution of virulence phenotypes among chlamydial species. 


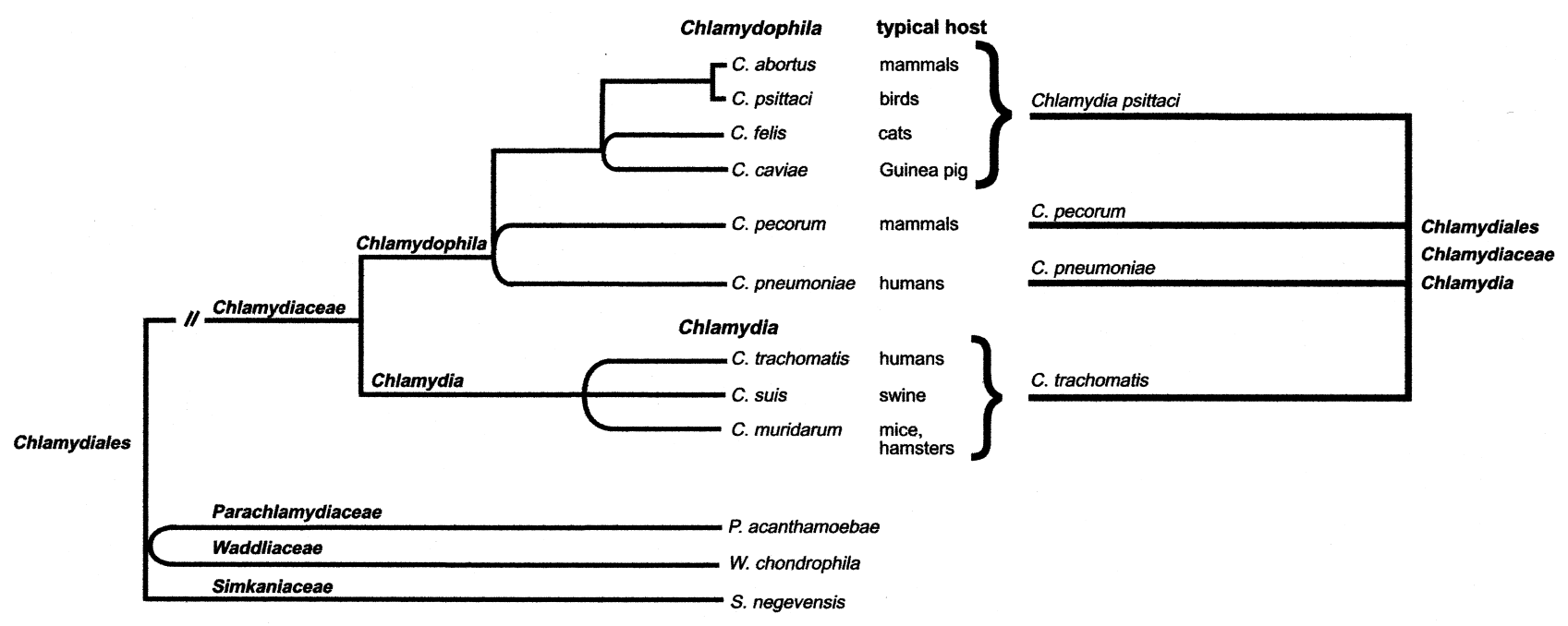

1a. new taxonomy

1b. old taxonomy

Fig. 1. Genetic structure of the order Chlamydiales. The tree on the left (a) depicts the recent taxonomic revision of the Chlamydiales (Everett et al., 1999a; Rurangirwa et al., 1999). Horizontal distances are roughly proportional to genetic distances as measured by 16S rRNA sequence data and DNA-DNA hybridization. A list of typical hosts illustrates the ecological heterogeneity of Chlamydiaceae species. Parachlamydiaceae are found in amoebae, and a second genus in this family, Neochlamydia, has recently been described (Horn et al., 2000). Host ranges of strains outside the Chlamydiaceae are not yet well resolved. Curved nodes show where the order of divergence is still unresolved. (b) Taxonomy of the Chlamydiales prior to revision.

Prior to the availability of molecular and genetic phylogenies, our ability to study virulence within an evolutionary context was severely limited. The intracellular lifestyle of chlamydiae obscures phenotypic characters and causes difficulties in isolation, culture and identification. In the absence of genetic analysis, only a small set of biochemical, physiological, morphological, serological and DNA-DNA hybridization data can be used to distinguish chlamydial species (reviewed by Everett et al., 1999a). Those characters allowed the identification of only four chlamydial species (Fig. 1b). However, several of the four species clearly encompassed clusters of biologically and ecologically differentiated strains (Herring, 1993), a problem corrected by our recent taxonomic revision (Fig. 1a, Table 1) (Everett et al., 1999a).

Previous efforts to correlate genetic sequence variation with virulence phenotype among serotypically distinguishable chlamydiae were primarily undertaken through analysis of the MOMP gene, a surface antigen (Baehr et al., 1988; Carter et al., 1991; Fitch et al., 1993; Kaltenboeck et al., 1993; Stephens et al., 1987; Zhang et al., 1993). According to Stothard et al. (1998), MOMP sequence variation appears to be a microevolutionary response to immune pressure. Variation in a few Chlamydia trachomatis MOMP sequences has also been explained by invoking lateral gene transfer (LGT) (Fitch et al., 1993; Hayes et al., 1994). Recent studies showing that a large number of sequences in the genomes of both Chlamydia trachomatis and Chlamydophila pneumoniae appear to be distantly related to genes in plants and other organisms has encouraged such hypotheses (Stephens et al., 1998; Wolf et al., 1999). Doolittle (1999) suggests that lateral transfer is a frequently observed method for transferring virulence traits among free-living bacterial species. However, Stiller \& Hall (1999) caution that apparent LGT can also be readily inferred from an erroneous phylogeny. The potential for making such an error is great in the chlamydiae, as homoplasy and the lack of appropriate outgroups make chlamydial phylogenetics problematic (Everett et al., 1999a; Herrmann et al., 2000; Pettersson et al., 1997). Thus, one goal of this work is to examine the hypothesis of lateral transfer within the Chlamydiaceae.

The molecular genetic analyses that contributed to the phylogenetic revision illustrated in Fig. 1(a) were limited to the $16 \mathrm{~S}$ and $23 \mathrm{~S}$ full-length ribosomal genes. Our current investigation focuses on coding genes for which multiple sequences are available from diverse chlamydial species. These include MOMP, the small cysteine-rich lipoprotein, and the $60 \mathrm{kDa}$ cysteine-rich protein, all components of the bacterial envelope. We have also studied the GroEL chaperonin, which is involved in the stimulation of host inflammatory responses and scarring (LaVerda et al., 1999), KDOtransferase, which is required for synthesis of LPS, a surface-exposed lipopolysaccharide, and an expanded ribosomal dataset. We examine the evolution of these six genetic loci with respect to the distribution of virulence traits in the Chlamydiaceae. We examine the genetic isolation of the newly described chlamydial 
These data do not include cross-species experimental studies or cases of disease in immunocompromised hosts. Cases were excluded when the species of infecting chlamydiae was not conclusively confirmed by genetic or other analysis (e.g. Moazed et al., 1998; Hemsley \& Canfield, 1996, 1997; Page, 1966, 1967; Saikku et al., 1998; Batta et al., 1999; Kik et al., 1997; Cotter et al., 1997; Amin \& Wilsmore, 1995; Yang et al., 1983). References: Chlamydia trachomatis (Branigan et al., 1996; Gerard et al., 1998; Koehler et al., 1997; de la Monte \& Hutchins, 1985; Stagg et al., 1996; Stephens, 1999; Wilkinson et al., 1998; Zollner et al., 1993); Chlamydia suis (Carrasco et al., 2000; Chae et al., 1999; Nietfeld et al., 1997; Rogers et al., 1996; Rogers \& Andersen, 1996; Sharma et al., 1999); Chlamydia muridarum (Fox et al., 1993, 1994;

Hildebrandt, 1982; Lindsey et al., 1982; Nigg, 1942; Perry \& Hughes, 1999); Chlamydophila psittaci (Grimes, 1985; Storz et al., 1963; Takahashi et al., 1988a, b; Vanrompay et al., 1995); Chlamydophila pneumoniae (Balin et al., 1998; Forsey \& Darougar, 1984; Glassick et al., 1996; Jackson et al., 1997; McChesney et al., 1982; Mair \& Wills, 1992; Moazed et al., 1998; Wardrop et al., 1999; Wilkinson et al., 1998); Chlamydophila pecorum (Glassick et al., 1996; Hemsley \& Canfield, 1996; Jones et al., 1998; Page, 1966; Philips \& Clarkson, 1998; Rodolakis \& Souriau, 1992; Takahashi et al., 1988b); Chlamydophila felis (Gaillard et al., 1984; TerWee et al., 1998); Chlamydophila caviae (Gordon et al., 1966; Murray, 1964; Patterson \& Rank, 1996; Prain \& Pearce, 1989; Rank et al., 1981, 1985, 1993; Rank \& Sanders, 1992); Chlamydophila abortus (Amin \& Wilsmore, 1995; Andersen, 1991; Clarkson \& Philips, 1997; Denamur et al., 1991; Guscetti et al., 1998; Jones et al., 1998; Page, 1966, 1967; Rodolakis et al., 1989; Storz et al., 1960). +, Published; blank, unpublished or unknown; dissemination in blood, published or inferred from publication. Information may be incomplete due to limited data for some species.

\begin{tabular}{|c|c|c|c|c|c|c|c|c|c|}
\hline & \multicolumn{3}{|c|}{ Chlamydia } & \multicolumn{6}{|c|}{ Chlamydophila } \\
\hline $\begin{array}{l}\text { Disseminated in } \\
\text { bloodstream }\end{array}$ & + & & & + & + & + & + & & + \\
\hline Typical host (s) & Humans & Swine & $\begin{array}{l}\text { Mice, } \\
\text { hamsters }\end{array}$ & Birds* & $\begin{array}{c}\text { Humans, } \\
\text { koalas*, } \\
\text { horses }\end{array}$ & $\begin{array}{l}\text { Cattle, } \\
\text { sheep, goats, } \\
\text { pigs, koalas }\end{array}$ & House cats* & Guinea pigs & $\begin{array}{l}\text { Sheep, } \\
\text { mammals* }\end{array}$ \\
\hline Infected tissues & $\begin{array}{l}\text { Eye } \dagger \text {, genital, joints, } \\
\text { neonate lung, prostate }\end{array}$ & $\begin{array}{l}\text { Eye†, } \\
\text { intestine, } \\
\text { lung }\end{array}$ & $\begin{array}{l}\text { Genital, } \\
\text { intestine, } \\
\text { liver, lung, } \\
\text { kidney, } \\
\text { spleen }\end{array}$ & $\begin{array}{l}\text { Brain, } \\
\text { eyet, } \\
\text { genital, intestine, } \\
\text { liver, lung, } \\
\text { spleen }\end{array}$ & $\begin{array}{l}\text { Arteries, } \\
\text { brain, } \\
\text { joints, } \\
\text { lung }\end{array}$ & $\begin{array}{l}\text { Bladder, } \\
\text { brain, } \\
\text { eye†, } \\
\text { intestine, lymph, } \\
\text { joints, } \\
\text { prostate }\end{array}$ & $\begin{array}{l}\text { Eye广, } \\
\text { genital, } \\
\text { joints, } \\
\text { lung }\end{array}$ & $\begin{array}{l}\text { Bladder, } \\
\text { eyet, } \\
\text { genital, } \\
\text { lung }\end{array}$ & $\begin{array}{l}\text { Intestine, } \\
\text { placenta, } \\
\text { spleen, } \\
\text { fetal liver }\end{array}$ \\
\hline
\end{tabular}

* Strains or biovars of these chlamydial species are occasionally found in alternate hosts. For example, Chlamydophila psittaci, Chlamydophila abortus and Chlamydophila feli. have been found in humans (Schachter et al. 1969: CDC, 1998; Herring, 1993; Jorgensen, 1997), with mortality particularly associated with Chlamvdophila psittaci pneumonitis and Chlamydophila abortus abortion. Chlamydophila psittaci has been found in dying tortoises (Vanrompay et al., 1994), a cat (Lipman et al., 1994) and cattle (Cox et al., 1998; Page, 1967); Chlamydophila pneumoniae was associated with disease in a dying giant barred frog in Australia (Berger et al., 1999) and in frogs imported to the USA from Africa (Reed et al., 2000).

$\dagger$ Conjunctiva of the eye. 
species and look for evidence that LGT might have influenced the distribution of virulence traits among chlamydial species. Our ultimate goal is to use studies of the molecular evolution of genes involved in immunity and disease to better understand how virulence and survival strategies have evolved among chlamydial species.

\section{METHODS}

Sequence acquisition and alignment. Several sequences were provided prior to release by R. J. Birtles, B. Herrmann, B. Kaltenboeck and F. R. Ruringawa. Sequences available in GenBank as of December 1999 were obtained for the ribosomal operon, GroEL chaperonin, KDO-transferase, the cysteine-rich lipoprotein, the $60 \mathrm{kDa}$ cysteine-rich protein and MOMP. Use of Chlamydia trachomatis MOMP sequences (from the 55 in GenBank) was limited to selected serotypes. Additional MOMP sequences for FP Baker, FP Cello, GPIC and MN Zhang were scanned from the original publications (May et al., 1996; Zhang et al., 1989). Resequencing of the FP Cello and FP Baker MOMP genes showed them to be identical to one another. Portions of the $16 \mathrm{~S}$ rRNA gene from N16 and all of the 16S rRNA gene from SFPD were resequenced. The lipoprotein genes from B/TW-5/OT and L2/434/BU were also resequenced and minor corrections were made as necessary (see Figures). New MOMP sequences were determined by W. A. Hambly; new lipoprotein, $60 \mathrm{kDa}$, and some additional MOMP sequences, were determined by K. D. E. Everett. Sequences were assembled using Sequencher data analysis software (Gene Codes). All new sequences were double-stranded data obtained directly from PCR products using automated DNA cycle sequencing and fluorescent dye terminators (Rosenblum et al., 1997). Sequencing and oligonucleotide primer synthesis were performed by the Iowa State University DNA Sequencing and Synthesis Facility, Ames, IA, USA. Bacterial strains and GenBank accession numbers (including multiple strains with identical sequences) are noted in the Figures and documented in GenBank and in original publications. Scanned and new data produced in this study have GenBank accession numbers AF269256-AF269282 and AF240773.

Sequences were aligned using CLUSTAL W (Thompson et al., 1994) and corrected by eye. Outgroups were identified by using BLAST searches (http://www.ncbi.nlm.nih.gov). Saturation plots (see below) were used to identify appropriate outgroup sequences. Excessive homoplasy prevented the use of outgroups, except for rRNA and GroEL. The analyses of three genes (the GroEL chaperonin, the $60 \mathrm{kDa}$ cysteinerich protein and KDO-transferase) each included a small number of sequences that were substantially shorter than the rest of the sequences in those datasets. These short sequences were included because they were representative of poorly sampled species. Short sequences were used only if their inclusion did not alter the structure of the tree produced using full-length sequences. Sequence alignments can be obtained from R. M. Bush (rmbush@uci.edu) or as supplementary data in IJSEM Online (http://ijs.sgmjournals. org/).

MOMP (ompA, omp*). MOMP is a surface-exposed porin that, upon reduction in the host cell, permits the entry of essential molecules and nutrients and may permit the exit of virulence factors. Genetic variation in the four hypervariable MOMP segments suggests that these are under intense selective pressure by host immune systems (Brunham et al.,
1994; Stothard et al., 1998). The aligned omp $A$ dataset of 1236 nucleotides (412 residues) contained 58 sequences representing all nine species in the Chlamydiaceae. We analysed sequences starting with the N-terminus of the posttranslationally processed protein because the 22/23-residue signal sequence data can sometimes include PCR amplification primer sequences. N-terminal data were missing from LW508 (14 residues), LW613 (16 residues), and 66p130 (22 residues), and 12 residues were missing at their Ctermini. Skua R54 was missing $30 \mathrm{~N}$-terminal residues and 11 C-terminal residues. Chlamydia suis and Chlamydophila abortus sequences numbered AJ004873-AJ005617 were missing 37 C-terminal residues. The aligned protein dataset was analysed both with and without the four hypervariable segments (Fitch et al., 1993), which were difficult to align. In our aligned dataset these are residues 88-109, 165-190, 254-269 and 322-356.

GroEL chaperonin (encoded by the gene known as groEL or hypB). GroEL chaperonin triggers host inflammation and subsequent scarring (Ward, 1995). The aligned groEL chaperonin dataset of 1632 nucleotide positions (544 residues) contained 11 sequences representing seven Chlamydiaceae species. Three sequences, B577, AR-388 and FcStra, lacked 22 residues on the $5^{\prime}$ end and 25 residues on the $3^{\prime}$ end. The 'pigeon' sequence lacked the first 128 residues. We included one outgroup sequence, from Rhodothermus marinus, in the analysis.

KDO-transferase ( $k d t A$; previously gse $A$ ). KDO-transferase catalyses the addition of three 3-deoxy-D-manno-2-octulosonic acid molecules onto lipid A precursors in the synthesis of chlamydial LPS. LPSs are generally endotoxins in Gram-negative bacteria, and chlamydial LPS is a mitogen. However, there is little evidence for chlamydial LPS induced endotoxic shock (Kosma, 1999), despite evidence for transport of most chlamydial species in the bloodstream (Table 1). The aligned $k d t A$ dataset of 1314 nucleotide positions (438 residues) contained 13 sequences representing five species from the Chlamydiaceae. Sequences from strains B577, FcStra and AR-388 each lacked 69 residues on the 5' end and 108 residues on the $3^{\prime}$ end.

Small cysteine-rich lipoprotein (omp3, envA, omcA, omIA). The cysteine-rich lipoprotein is an important structural constituent of the chlamydial outer envelope (Hatch, 1996). The aligned small cysteine-rich lipoprotein dataset of 279 aligned nucleotide positions (93 residues) contained seven sequences representing five species from the Chlamydiaceae.

Large cysteine-rich $60 \mathrm{kDa}$ protein (omp2, ompB, envB, omcB, cmcB). The $60 \mathrm{kDa}$ cysteine-rich protein is a periplasmic structural constituent of the chlamydial envelope (Hatch, 1996). The aligned $60 \mathrm{kDa}$ cysteine-rich protein dataset of 1677 nucleotides (559 residues) contained 14 sequences representing six species from the Chlamydiaceae. Four sequences, KC, N16, E58 and Koala lacked 380 of the 559 residues. These sequences began at residue 12 and ended around residue 191 .

Ribosomal operon and ribosomal construct. Full-length sequence data for the entire ribosomal operon are available for at least two strains in each of six species. Data for only one full-length operon is available for each of Chlamydophila caviae, Chlamydophila felis and Chlamydophila abortus. The sequence data for isolate N16 are not full-length, beginning at position 53. Two different ribosomal datasets were analysed. Each was a subset of the full-length, contiguous $16 \mathrm{~S}$ and $23 \mathrm{~S}$ rRNA data. The dataset we termed the 'ribosomal operon' was a contiguous dataset containing 
2708 aligned nucleotide positions that started at position 8 of the 1566 bp 16S rRNA gene (Escherichia coli numbering), continued through the $16 \mathrm{~S} / 23 \mathrm{~S}$ intergenic spacer, and included the most diverse segment (the first 851 bases) of the approximately $3000 \mathrm{bp} 23 \mathrm{~S}$ rRNA gene. We also analysed a dataset called the 'ribosomal construct', which was the 'ribosomal operon' with the genetically heterogeneous (and thus difficult to align) intergenic spacer removed. (There was almost no sequence identity between the Chlamydiaceae and outgroup families in the intergenic spacer.) This permitted an analysis of 20 chlamydial isolates representing all nine Chlamydiaceae species. Outgroup sequences were obtained and used for three recently described families in the Chlamydiales: Parachlamydiaceae, Simkaniaceae and Waddliaceae.

Phylogenetic analysis. Phylogenetic trees were constructed using PAUP* version 4.0b4 (Swofford, 2000). A variety of algorithms were used: quartet puzzling (QP), maximumlikelihood (ML), maximum-parsimony (MP) and neighbour-joining (NJ). MP and $\mathrm{NJ}$ analyses were run 10 times, randomizing in each run the order in which the sequences were input. All analyses except QP were run using both nucleotide sequences and the corresponding amino acids for coding genes. The QP nucleotide trees are shown in the Figures, and variation among trees produced in different analyses is described in the results. Reliability values from the QP analysis are shown for each node when greater than or equal to $75 \%$. These values are the percentage of times a node was seen in 1000 of the intermediate trees produced in the QP routine (Strimmer \& von Haeseler, 1996). For MP analyses, the tree bisection-reconnection branch swapping option of the heuristic search routine was used. MP bootstrap values are shown parenthetically with corresponding QP reliability values when the bootstrap values were less than or equal to $75 \%$. The phylogenetic distribution of insertions and deletions (INDELs) was examined by eye (Gupta, 1998).

Genetic differentiation of chlamydial species. Distinctness ratios contrast the genetic distances between groups of isolates with respect to the variation within those groups (Palys et al., 1997). When a distinctness ratio calculated using one sequence or gene differs greatly from ratios calculated using other sequences or genes, the data should be examined for recombination events, strain contamination or misidentification of isolates. A distinctness ratio is the ratio of the mean between-taxa genetic divergence to mean withintaxon divergence. The mean within-taxon divergence for a species pair is the mean of the two within-taxon divergence values. Mean distinctness ratios were calculated across all pairwise comparisons of nucleotide sequences for all six loci. Gapped positions were not included in these calculations. According to the criteria of Palys et al. (1997), distinctness ratios of two or greater are sufficient to define genetically distinct species. Distinctness ratios were calculated for the MOMP gene and the ribosomal operon with and without the four variable segments and the intergenic spacer, respectively.

Saturation analysis. Saturation plots were used to evaluate the degree of homoplasy in each dataset. A saturation plot contrasts the phyletic and percentage pairwise genetic distances between pairs of isolates (Vuillaumier et al., 1997). The percentage pairwise genetic distance between two sequences was calculated as the percentage of non-gapped nucleotide positions at which the two sequences differed. The phyletic distance used was the ML estimate of genetic distance between two isolates produced in the QP analyses, in nucleotide substitutions per site. When pairwise and phyletic distances are identical, the slope of a regression line drawn through the points on a saturation plot is linear and has a slope of 1 . Phyletic distances increase more rapidly than pairwise distances when multiple nucleotide changes per position occur over time. As the frequency of multiple mutations per position increases, the correlation between the phyletic and pairwise distance declines. When no correlation remains (as the slope approaches zero), mutational saturation is said to have occurred, and processes such as longbranch attraction (Felsenstein, 1978) rather than relatedness might be determining the attachment of branches between distantly related clades. Saturation plots were useful for evaluating the appropriateness of potential outgroups for the Chlamydiaceae and for evaluating homoplasy within the Chlamydiaceae as well.

\section{RESULTS}

\section{MOMP}

The unrooted MOMP QP tree contained sequences from all nine species in the Chlamydiaceae (Fig. 2). The reliability value from the QP analysis provided $100 \%$ support for the separation of Chlamydia and Chlamydophila. All analyses showed Chlamydophila abortus evolving from, rather than as a sister clade to, Chlamydophila psittaci. All of the nodes within the Chlamydiaceae depicted by curved lines in Fig. 1(a) were difficult to resolve in the MOMP analysis. Different topologies were produced, depending on the algorithm, on whether full-length data were used or variable segments were removed, and on whether nucleotide or protein data were used. This was most likely due to excessive homoplasy, as the phyletic distances were substantially larger than pairwise genetic distances between the genera and even for some of the between-species comparisons (Fig. 3, shown with the MOMP variable segments removed). Evidence that homoplasy might be interfering with phylogenetic reconstruction through long branch attraction was most apparent under maximum-parsimony. Using MP, the three Chlamydia species (Chlamydia suis, Chlamydia trachomatis and Chlamydia muridarum) did not form discrete clades when the variable segments of the MOMP genes were included in the analysis. When separate analysis of each genus was performed under MP, Chlamydia suis, Chlamydia trachomatis and Chlamydia muridarum were clearly differentiated.

\section{GroEL chaperonin}

The GroEL chaperonin QP tree (Fig. 4) was congruent with the consensus tree in Fig. 1(a) except that it lacked sequences for Chlamydia suis and Chlamydophila felis. The GroEL chaperonin was the least genetically differentiated of the coding genes. The outgroup, Rhodothermus marinus, was as similar to the Chlamydiaceae in analysis of GroEL (58\% at the nucleotide level) as Chlamydia and Chlamydophila were to each other in analysis of KDO-transferase (Fig. 3). Phylogenetic reconstruction of the relationships between species was probably not affected by homoplasy, as 


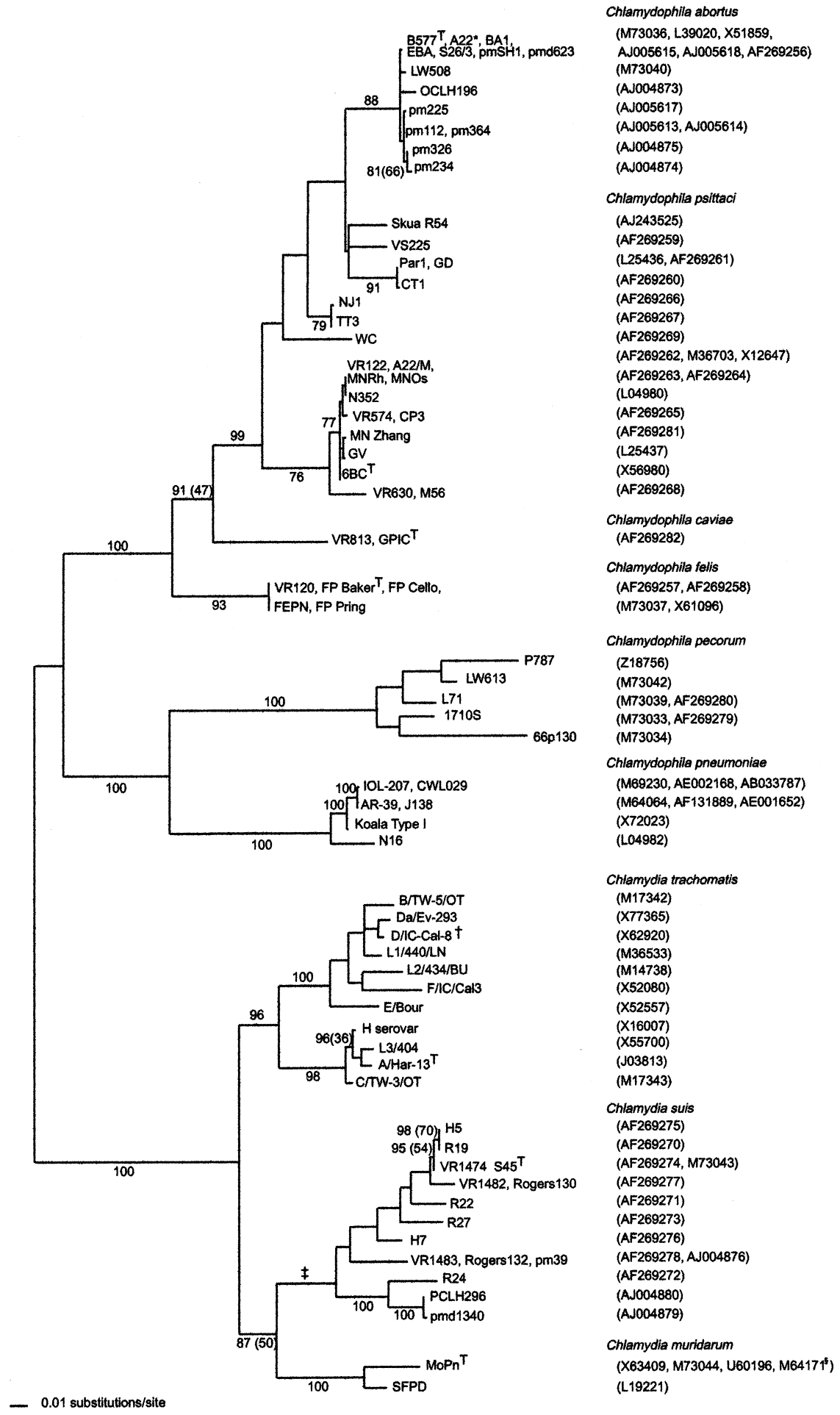

Fig. 2. MOMP phylogeny. QP tree constructed using the ompA gene, which encodes the MOMP. The four variable segments were excluded from this analysis. ATCC reference numbers and GenBank accession numbers are provided for each strain. QP reliability values are shown on each branch when greater than or equal to $75 \%$, MP bootstrap values at these nodes are shown in parentheses if less than or equal to $75 \%{ }^{\top}=$ type strain. *, A22 data were a personal communication from Alan Herring; $\dagger=\mathrm{D} / \mathrm{IC}-\mathrm{Cal}-8$ is identical to Da/TW-448 (X62921) and D/B-120 (X62928); $\$$, the reliability value for this node was only $58 \%$, while the bootstrap value was $89 \%$ (this likely reflects long-branch attraction, as QP and MP analyses using only isolates from the genus Chlamydia showed $100 \%$ reliability and bootstrap values for nodes separating the three Chlamydia species); §, MoPn sequence M64171 differs from the other MoPn sequences by 2 bases. 

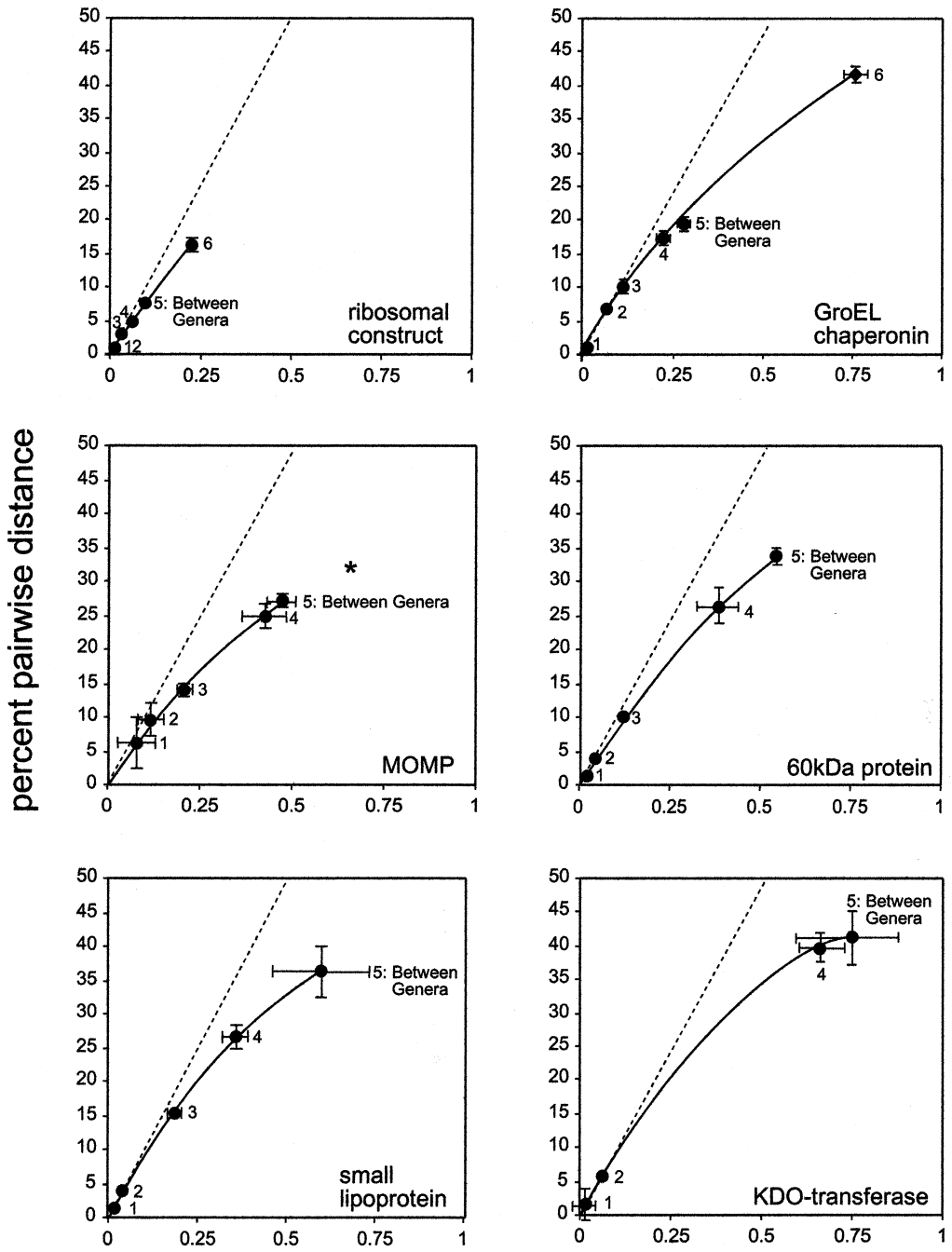

phyletic distance

Fig. 3. Mutational saturation plots. Contrasts of pairwise and phyletic distances from the QP trees in Figs 2, 4 and 5. The percentage pairwise distance is the percentage of non-gapped nucleotide positions that differed between sequences. The phyletic distance is the maximumlikelihood estimate of the genetic distance between sequences in nucleotide substitutions per site. Each point represents the mean \pm one standard deviation. In each graph, distances are labelled as follows: 1, distances between isolates within species; 2, between Chlamydophila abortus and Chlamydophila psittaci; 3, between species derived from the former Chlamydia trachomatis and the former Chlamydophila psittaci; 4, between Chlamydophila pecorum and Chlamydophila pneumoniae, and between these two species and the rest of the species in the genus Chlamydophila; 5 , between genera; 6 , between the Chlamydiaceae and other families (when available). The asterisk on the MOMP plot shows the between-genus contrast, had the variable segments been included. Each diagonal line indicates the predicted plot if phyletic and pairwise distances had been equal. without the outgroup all analyses produced the same tree structure, and the phyletic distances were comparable to pairwise genetic distances (Fig. 3). However, analyses including the $R$. marinus outgroup varied according to the algorithm or type of data used. The QP analysis and the MP analysis of amino acids rooted the Chlamydiaceae so that the two genera were monophyletic lineages. However, MP analysis of nucleotide data and $\mathrm{NJ}$ analysis gave a variety of other results. Saturation analysis suggested that $R$. marinus was probably too distantly related to serve as a reliable outgroup (Fig. 3).

\section{KDO-transferase}

The unrooted KDO-transferase QP tree (Fig. 4) included only five Chlamydiaceae species but was otherwise congruent with the consensus tree in Fig. 1(a). KDO-transferase sequences were the most genetically differentiated data in this study. Saturation analysis suggested that homoplasy might affect phylogenetic reconstruction of the family even without the presence of outgroups in the analysis (Fig. 3). The relationships among species did not vary when different phylogenetic algorithms were used. However, the use of different algorithms affected apparent relationships among Chlamydia trachomatis strains and caused variation in which the Chlamydia trachomatis isolate was apparently closest to the root of the Chlamydia trachomatis clade, a result typical of long-branch attraction.

\section{Small cysteine-rich lipoprotein}

The unrooted QP tree for the small cysteine-rich lipoprotein was congruent with the consensus tree in Fig. 1(a), except that it contained only five species (Fig. 4). The tree showed Chlamydophila caviae as a sister taxon to Chlamydophila pneumoniae. This would probably not have occurred had a representative of Chlamydophila pecorum been present in the dataset (this configuration had zero bootstrap support in MP analysis). Results did not vary when different phylogenetic algorithms were used. 


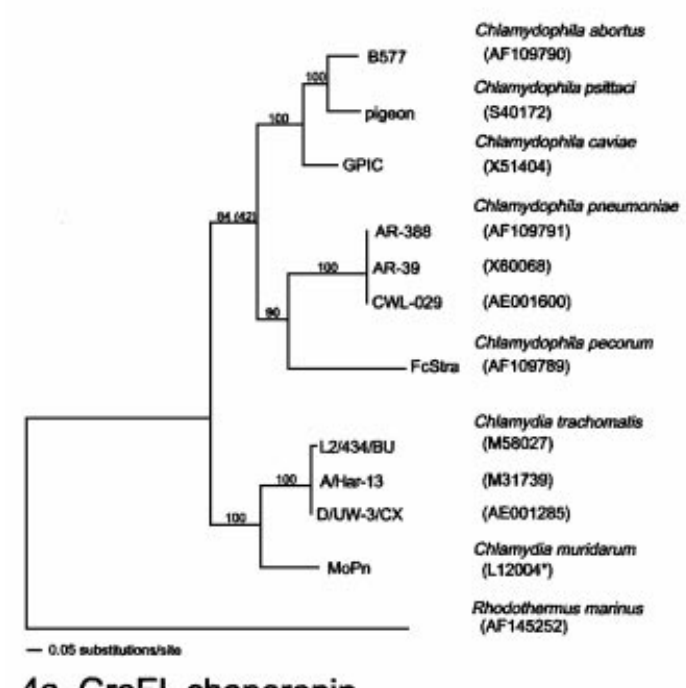

4a. GroEL chaperonin

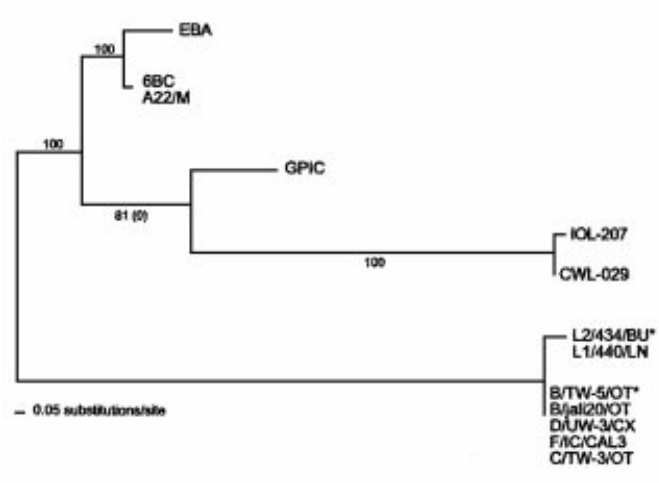

4c. small cysteine-rich lipoprotein

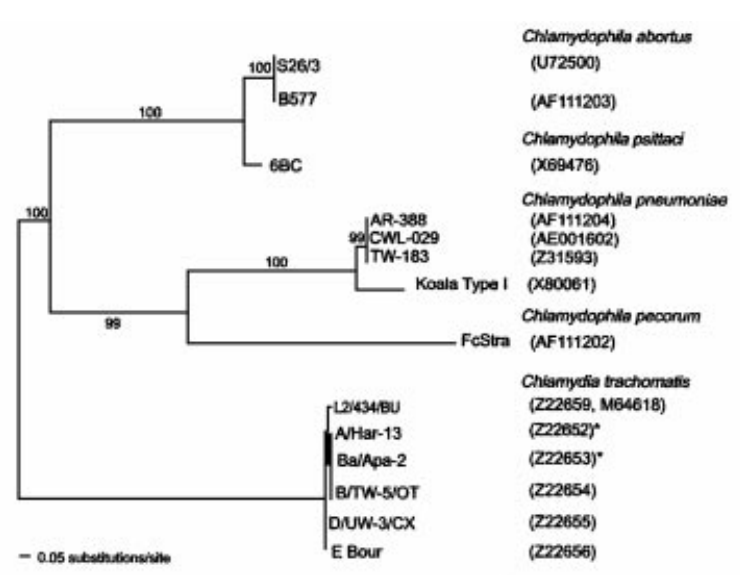

4b. KDO-transferase
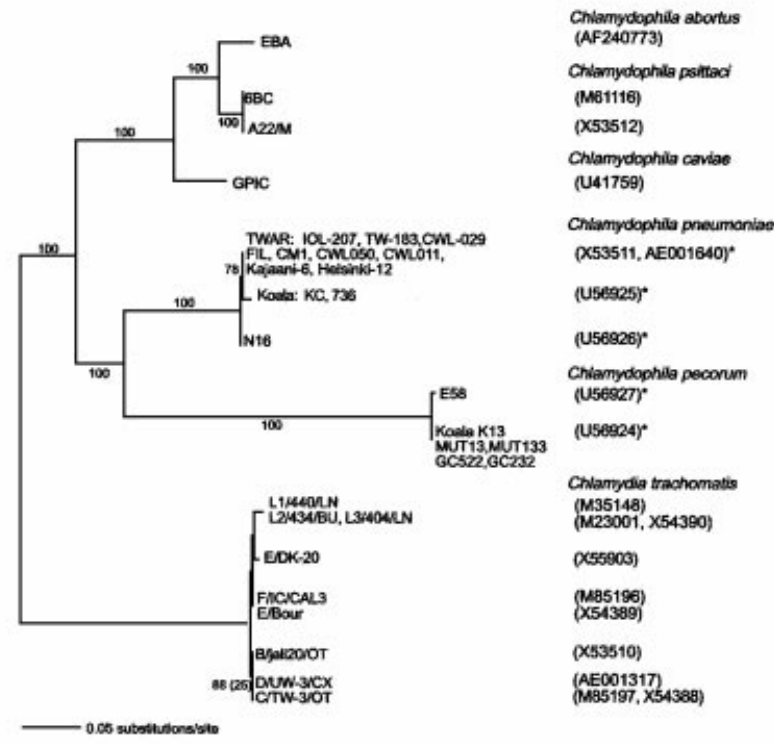

4d. large cysteine-rich $60-\mathrm{kDa}$ protein

Fig. 4. Four coding gene phylogenies. QP trees were constructed using the nucleotide sequences of four coding genes. (a) GroEL chaperonin; *L12004 was used for MoPn in this alignment; MoPn sequence U52049 differs from L12004 by 4 bases. (b) KDO-transferase; *Z22652-Z22654 genes differ by two or three nucleotides but have identical amino acid sequences. (c) Small cysteine-rich lipoprotein; *a 2-base inversion sequencing error was corrected in these sequences. (d) $60 \mathrm{kDa}$ cysteine-rich protein. ATCC and GenBank numbers are provided for each strain. QP reliability values are shown on each branch when greater than or equal to $75 \%$, MP bootstrap values at these nodes are shown in parentheses if less than or equal to $75 \% .^{\top}=$ type strain.

\section{Large cysteine-rich 60 kDa protein}

The unrooted QP tree constructed using the gene for the large cysteine-rich $60 \mathrm{kDa}$ protein contained six species (Fig. 4) and was otherwise congruent with the consensus tree (Fig. 1a). The differentiation of species and the order in which species diverged were consistent using the various algorithms. The saturation plot indicated some homoplasy in the dataset for this gene (Fig. 3). The Chlamydia trachomatis isolate that was closest to the root of the Chlamydia trachomatis clade, and the relationships among the Chlamydia trachomatis strains, varied among the different analyses. This pattern, also seen with KDO-transferase, is typical of long-branch attraction.

\section{Ribosomal operon}

The ribosomal operon was the only genetic locus for which sequences from all nine Chlamydiaceae species and closely related outgroups were available (Fig. 5). The QP ribosomal tree was congruent with the consensus tree previously determined using other algorithms (Fig. 1a). Support was present but not strong in any analysis for pairing Chlamydophila pecorum and Chlamydophila pneumoniae as sister taxa. QP did not resolve the order of divergence of Chlamydophila caviae and Chlamydophila felis, but otherwise provided a branching order that had good statistical support regardless of whether the intergenic spacer was included (Fig. 5 shows the tree constructed 


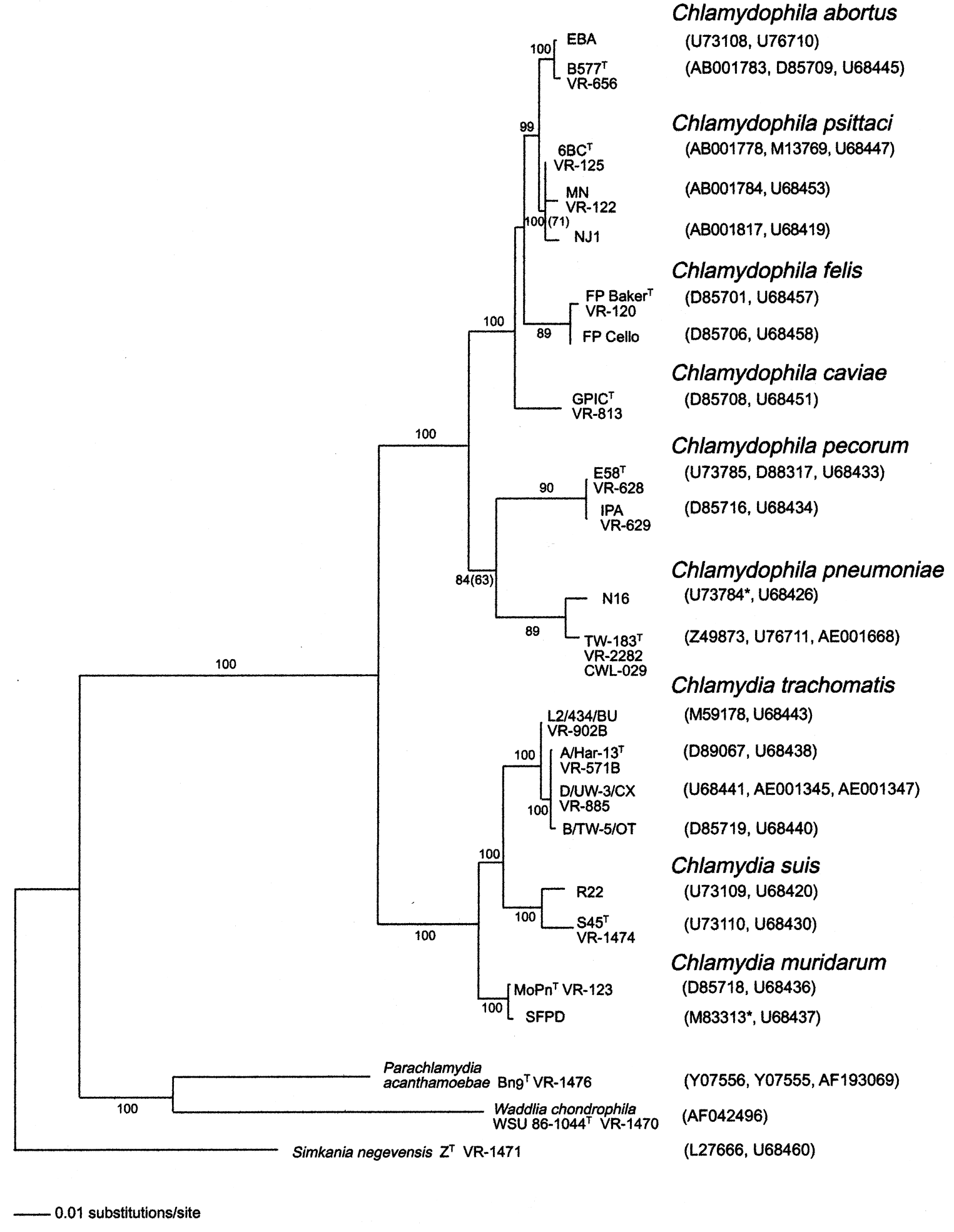

Fig. 5. Ribosomal phylogeny. QP tree using a ribosomal construct containing the $16 \mathrm{~S}$ rRNA and the first 851 bases of the 235 rRNA gene. ATCC reference numbers and GenBank accession numbers are provided for each strain. QP reliability values are shown on each branch when greater than or equal to $75 \%$, MP bootstrap values at these nodes are shown in parentheses if less than or equal to $75 \% .^{\top}=$ type strain; *including new or resequenced data.

without the spacer). The three outgroup sequences were as genetically distant from one another as they were from the family Chlamydiaceae. Waddlia and
Parachlamydia were sister taxa in all analyses. The saturation plot for this ribosomal segment showed a close correspondence of pairwise and phyletic 
Table 2. Distinctness ratios for species in the Chlamydiaceae

The ratio of between-taxa to within-taxa divergence (Palys et al., 1997) for the ribosomal construct and for omp $A$ without the four variable segments.

\begin{tabular}{|c|c|c|c|c|c|c|c|c|c|}
\hline \multirow[t]{2}{*}{ Species 1} & \multirow[t]{2}{*}{ Species 2} & \multicolumn{4}{|c|}{ Ribosomal construct } & \multicolumn{4}{|c|}{ ompA (МOMP) } \\
\hline & & $\begin{array}{c}\text { Mean } \\
\text { divergence } \\
( \pm \text { SE) within } \\
\text { Species 1 }\end{array}$ & $\begin{array}{c}\text { Mean } \\
\text { divergence } \\
( \pm \text { SE) within } \\
\text { species } 2\end{array}$ & $\begin{array}{c}\text { Mean } \\
\text { divergence } \\
( \pm \text { SE) between } \\
\text { species } 1 \text { and } 2\end{array}$ & $\begin{array}{c}\text { Ratio } \\
\text { between/within }\end{array}$ & $\begin{array}{l}\text { Mean divergence } \\
( \pm \text { SE) within } \\
\text { species 1 }\end{array}$ & $\begin{array}{l}\text { Mean divergence } \\
( \pm \text { SE) within } \\
\text { species } 2\end{array}$ & $\begin{array}{l}\text { Mean divergence } \\
( \pm \text { SE) between } \\
\text { species } 1 \text { and } 2\end{array}$ & $\begin{array}{c}\text { Ratio } \\
\text { between/within }\end{array}$ \\
\hline \multicolumn{10}{|l|}{ Chlamydophila } \\
\hline abortus & felis & $0 \cdot 003$ & 0.003 & $0 \cdot 023 \pm 0 \cdot 001$ & $8 \cdot 54$ & $0 \cdot 008 \pm 0 \cdot 004$ & $0 \cdot 001 \pm 0 \cdot 001$ & $0 \cdot 138 \pm 0 \cdot 005$ & $30 \cdot 35$ \\
\hline psittaci & felis & $0.005 \pm 0.002$ & $0 \cdot 003$ & $0.021 \pm 0.002$ & $5 \cdot 51$ & $0.070 \pm 0.039$ & $0 \cdot 001 \pm 0 \cdot 001$ & $0 \cdot 133 \pm 0 \cdot 007$ & $3 \cdot 72$ \\
\hline abortus & caviae & $0 \cdot 003$ & & $0.020 \pm 0.001$ & 8.00 & $0 \cdot 008 \pm 0 \cdot 004$ & & $0 \cdot 137 \pm 0 \cdot 005$ & 17.92 \\
\hline psittaci & caviae & $0 \cdot 005 \pm 0 \cdot 002$ & & $0.020 \pm 0.002$ & $4 \cdot 24$ & $0.070 \pm 0.039$ & & $0 \cdot 134 \pm 0 \cdot 006$ & 1.92 \\
\hline felis & caviae & $0.003^{-}$ & & 0.025 & $8 \cdot 36$ & $0 \cdot 001 \pm 0 \cdot 001$ & & $0 \cdot 133 \pm 0 \cdot 001$ & $92 \cdot 30$ \\
\hline abortus & pecorum & $0 \cdot 003$ & $0 \cdot 001$ & $0 \cdot 043 \pm 0 \cdot 001$ & $25 \cdot 67$ & $0 \cdot 008 \pm 0 \cdot 004$ & $0 \cdot 092 \pm 0 \cdot 026$ & $0 \cdot 273 \pm 0 \cdot 011$ & $5 \cdot 49$ \\
\hline psittaci & pecorum & $0 \cdot 005 \pm 0 \cdot 002$ & $0 \cdot 001$ & $0 \cdot 043 \pm 0 \cdot 001$ & $15 \cdot 35$ & $0 \cdot 070 \pm 0.039$ & $0 \cdot 092 \pm 0 \cdot 026$ & $0 \cdot 260 \pm 0 \cdot 012$ & $3 \cdot 21$ \\
\hline felis & pecorum & $0 \cdot 003$ & $0 \cdot 001$ & $0 \cdot 049 \pm 0 \cdot 001$ & $25 \cdot 83$ & $0 \cdot 001 \pm 0 \cdot 001$ & $0 \cdot 092 \pm 0 \cdot 026$ & $0 \cdot 260 \pm 0 \cdot 007$ & $5 \cdot 58$ \\
\hline caviae & pecorum & & $0 \cdot 001$ & $0 \cdot 050$ & $59 \cdot 81$ & & $0 \cdot 092 \pm 0 \cdot 026$ & $0 \cdot 255 \pm 0 \cdot 010$ & $2 \cdot 78$ \\
\hline abortus & pneumoniae & 0.003 & $0 \cdot 010$ & $0 \cdot 045 \pm 0.002$ & $7 \cdot 29$ & $0 \cdot 008 \pm 0 \cdot 004$ & $0 \cdot 025 \pm 0 \cdot 020$ & $0 \cdot 245 \pm 0 \cdot 007$ & $15 \cdot 08$ \\
\hline psittaci & pneumoniae & $0 \cdot 005 \pm 0 \cdot 002$ & $0 \cdot 010$ & $0 \cdot 043 \pm 0 \cdot 003$ & $5 \cdot 96$ & $0 \cdot 070 \pm 0.039$ & $0 \cdot 025 \pm 0 \cdot 020$ & $0 \cdot 234 \pm 0 \cdot 009$ & $4 \cdot 93$ \\
\hline felis & pneumoniae & $0 \cdot 003$ & $0 \cdot 010$ & $0 \cdot 048 \pm 0 \cdot 001$ & $7 \cdot 55$ & $0 \cdot 001 \pm 0 \cdot 001$ & $0 \cdot 025 \pm 0 \cdot 020$ & $0 \cdot 227 \pm 0 \cdot 005$ & $17 \cdot 30$ \\
\hline caviae & рпеитопiae & & $0 \cdot 010$ & $0 \cdot 050 \pm 0 \cdot 001$ & $5 \cdot 15$ & & $0 \cdot 025 \pm 0 \cdot 020$ & $0 \cdot 240 \pm 0 \cdot 005$ & $9 \cdot 68$ \\
\hline $\begin{array}{l}\text { pecorum } \\
\text { Chlamydia }\end{array}$ & pneumoniae & $0 \cdot 001$ & $0 \cdot 010$ & $0 \cdot 046 \pm 0 \cdot 001$ & 8.72 & $0 \cdot 092 \pm 0 \cdot 026$ & $0 \cdot 025 \pm 0 \cdot 020$ & $0 \cdot 231 \pm 0 \cdot 007$ & $3 \cdot 96$ \\
\hline trachomatis & muridarum & $0 \cdot 002 \pm 0 \cdot 001$ & $0 \cdot 002$ & $0.025 \pm 0.001$ & $12 \cdot 65$ & $0.067 \pm 0.030$ & $0 \cdot 051$ & $0 \cdot 142 \pm 0 \cdot 005$ & $2 \cdot 41$ \\
\hline trachomatis & suis & $0.002 \pm 0.001$ & $0 \cdot 014$ & $0.029 \pm 0.001$ & $3 \cdot 46$ & $0.067 \pm 0.030$ & $0 \cdot 065 \pm 0 \cdot 029$ & $0 \cdot 144 \pm 0.007$ & $2 \cdot 18$ \\
\hline muridarum & suis & 0.002 & 0.014 & $0.030 \pm 0.000$ & $3 \cdot 75$ & 0.051 & $0 \cdot 065 \pm 0.029$ & $0 \cdot 138 \pm 0.000$ & $2 \cdot 39$ \\
\hline
\end{tabular}


Table 3. INDEL analysis of the Chlamydiaceae

Full-length gene alignments were included, with the exception of the ribosomal intergenic spacer and variable segments of MOMP. There were no INDELs in the GroEL chaperonin.

\begin{tabular}{|c|c|c|c|c|c|c|}
\hline & Total & $\begin{array}{l}60 \mathrm{kDa} \\
\text { protein }\end{array}$ & $\begin{array}{c}\text { Small } \\
\text { lipoprotein }\end{array}$ & KDO-transferase & MOMP & $\begin{array}{c}\text { rRNA } \\
\text { construc }\end{array}$ \\
\hline \multicolumn{7}{|l|}{ Groups above the species level: } \\
\hline Differentiated the two genera & 2 & & & & & 2 \\
\hline $\begin{array}{l}\text { Grouped Chlamydophila pecorum and } \\
\text { Chlamydophila pneumoniae }\end{array}$ & 5 & & & 1 & 1 & 3 \\
\hline $\begin{array}{l}\text { Grouped Chlamydophila abortus and } \\
\text { Chlamydophila psittaci }\end{array}$ & 3 & & 2 & 1 & & \\
\hline $\begin{array}{l}\text { Grouped Chlamydophila abortus and } \\
\text { Chlamydophila psittaci and Chlamydophila caviae }\end{array}$ & 1 & & 1 & & & \\
\hline $\begin{array}{l}\text { Grouped Chlamydophila abortus and } \\
\text { Chlamydophila psittaci and Chlamydophila felis }\end{array}$ & 1 & & & & 1 & \\
\hline Subtotal: & 12 & & & & & \\
\hline \multicolumn{7}{|l|}{ Differentiated species: } \\
\hline Chlamydophila caviae & 2 & 1 & & & & 1 \\
\hline Chlamydophila pecorum & 3 & 1 & & & & 2 \\
\hline Chlamydophila pneumoniae & 2 & 1 & 1 & & & \\
\hline Chlamydia suis & 2 & & & 1 & & 1 \\
\hline Chlamydia muridarum & 2 & & & & & 2 \\
\hline Chlamydia trachomatis & 8 & 2 & 4 & 1 & & 1 \\
\hline Subtotal: & 19 & & & & & \\
\hline \multicolumn{7}{|l|}{ Differentiated isolate(s) within species: } \\
\hline Chlamydophila pneumoniae (Koala) & 1 & & & 1 & & \\
\hline Chlamydophila abortus (OCLH196) & 1 & & & & 1 & \\
\hline Chlamydophila pecorum (several isolates) & 1 & & & & 1 & \\
\hline Subtotal: & 3 & & & & & \\
\hline \multicolumn{7}{|l|}{ Inconsistent with phylogeny: } \\
\hline $\begin{array}{l}\text { Chlamydophila, without Chlamydophila felis and } \\
\text { Chlamydophila caviae }\end{array}$ & 1 & & & & & 1 \\
\hline $\begin{array}{l}\text { Mixed isolates from Chlamydia trachomatis and } \\
\text { Chlamydia suis }\end{array}$ & 1 & & & & & 1 \\
\hline Subtotal: & 2 & & & & & \\
\hline Total: & 36 & & & & & \\
\hline
\end{tabular}

distances, even between Chlamydiaceae and these outgroups (Fig. 3). Different algorithms produced the same tree structure except for the order of divergence of Chlamydophila caviae and Chlamydophila felis.

\section{Genetic differentiation of species}

Distinctness ratios calculated for nearly all genes and species were greater than or equal to $2 \cdot 0$, the value suggested as appropriate for species-level differentiation (Palys et al., 1997). The only exception was the Chlamydophila psittaci/Chlamydophila caviae contrast using MOMP with variable segments removed, which was $1 \cdot 9$. Table 2 shows these ratios for MOMP and for the ribosomal construct, the two datasets that included all nine species. When variable segments or intergenic spacer segments were included in the MOMP or ribosomal analyses, respectively, the results in Table 2 changed very little. Distinctness ratios were, on av- erage, smaller for MOMP than for the ribosomal construct. This was because within-species divergence (the denominator of the distinctness ratio) was about ten times greater for MOMP than for the ribosomal construct, while variation between species (the numerator) using MOMP was only about five times greater than for the ribosomal construct.

\section{INDEL analysis}

INDEL analysis (Table 3) suggested an evolutionary pattern that was almost entirely consistent with the reconstruction of chlamydial evolution shown in Fig. 1(a). The GroEL chaperonin lacked INDELs. The other five loci contained a total of 36 INDELs, 34 of which were consistent with the phylogeny in Fig. 1(a). Two INDELs in the ribosomal construct differentiated the two genera. Nineteen INDELs in four genes differentiated six of the nine species. The clade containing Chlamydophila pecorum and Chlamydophila 
pneumoniae was differentiated by five INDELs in three genes. The Chlamydophila abortus/Chlamydophila psittaci clade shared one INDEL in KDO-transferase and two in the small lipoprotein, and these two species shared an INDEL with Chlamydophila felis in the MOMP gene and with Chlamydophila caviae in the small lipoprotein. The additional three INDELs were strain specific. The two INDELs that were not concordant with Fig. 1(a) were both in the ribosomal construct. One INDEL grouped subsets of strains from Chlamydia trachomatis and Chlamydia suis. The other grouped Chlamydophila felis and Chlamydophila caviae with the genus Chlamydia. The ribosomal intergenic spacer and the variable segments of the MOMP gene contained large numbers of INDELs, but these segments were so difficult to align that we could not confidently draw inference from their INDELs. The INDELs in these hypervariable segments often differentiated isolates into clusters that were inconsistent with any reasonable phylogeny.

\section{DISCUSSION}

This study of the evolutionary history of five coding genes in the Chlamydiaceae (Figs 2 and 4) showed all genes evolving in concert with the ribosomal genes (Fig. 5), albeit at very different rates. The evolutionary structure of the family consisted of two monophyletic lineages, each containing deeply divergent clusters of sequences. Distinctness ratios calculated for each cluster met or exceeded the recommended values for species (Table 2) (Palys et al., 1997). The congruence of the individual gene trees, the support of these trees by analysis of INDELs, and the clear genetic separation of similarity clusters shown by distinctness ratios argue against the presence of interspecies recombination and incorrect strain or species identification in these data. We could not discern the order of divergence in a few places on our trees (nodes shown using curved lines on Fig. 1a), due to homoplasy; however, it was relatively easy to validate which nodes were robust by comparing results obtained by varying the phylogenetic algorithms, by saturation analysis, and by using both nucleotide and protein sequence data.

Clustering of isolates by genetic relatedness was consistent with a recent taxonomic revision of the family Chlamydiaceae (Everett et al., 1999a). This revision was multi-faceted, being based on biochemical, ecological and DNA-DNA hybridization data; however, the molecular phylogenetic analyses contributing to the revision were limited to ribosomal sequence data (Everett et al., 1999a). This ribosomal phylogeny, rooted with sequences from three new families in the Chlamydiales for both the full-length $16 \mathrm{~S}$ rDNA and the full-length $23 \mathrm{~S}$ rDNA for all species, showed the Chlamydiaceae radiating into two genera and a total of nine species. Thus, these results corroborate the recent phylogenetic revision, illustrated in Fig. 1(a), and are consistent with the proposed standard of 95,90 and $80 \%$ ribosomal sequence identity for separating genera, families and the order Chlamydiales, respectively (Everett et al., 1999a). This phylogeny can now be used as a foundation upon which to examine the evolution of additional genes, investigate evolutionary processes responsible for differences in virulence phenotype among species, and study the rate and direction of evolution of the important coding genes analysed here.

The five coding genes varied greatly in their rates of evolution, as can be seen by comparing the genetic distances separating the two genera (Fig. 6). The most rapidly evolving gene encodes KDO-transferase, an enzyme that synthesizes LPS. The most slowly evolving coding gene expresses GroEL chaperonin, which triggers host inflammation and subsequent scarring (Ward, 1995). The genes evolving at intermediate rates code for MOMP, cysteine-rich lipoprotein and cysteine-rich $60 \mathrm{kDa}$ protein. These genes, which are important structural constituents of the chlamydial envelope, have no known homologues in other bacterial species.

\section{The evolution of virulence}

One of the most striking observations about evolution within the Chlamydiaceae has been the reported lack of correlation between virulence phenotype and phylogenetic relatedness (Fitch et al., 1993; Stothard et al., 1998). However, those studies were based on a phylogeny that was not yet well resolved or on only a limited set of species, respectively. To determine if an improved phylogeny with more appropriate species designations explains the evolution of chlamydial virulence, we mapped the most commonly surveyed virulence characters from the literature onto the new chlamydial phylogeny (Table 1). This is also illustrated in Fig. 1(a) using host specificity traits. Our goal was to infer character states for the ancestors of the nine extant species using parsimony analysis, hoping to learn something about the processes driving the diversification within this group. Could chlamydial access to a host have occurred at the time of host speciation? The molecular phylogeny of Chlamydiaceae hosts was not at all congruent with the molecular phylogeny of Chlamydiaceae pathogens. Furthermore, there is not an appropriate fossil record that would provide a standard of measure for the divergence of chlamydiae relative to their hosts (Haag et al., 1998; Clark et al., 1999). Analysis of other virulence traits in Table 1 showed only a modest degree of phylogenetic pattern. Chlamydophila pneumoniae, Chlamydophila pecorum and Chlamydophila psittaci, for example, have all been isolated or identified from brain tissue of infected hosts, and both Chlamydophila pneumoniae and Chlamydophila psittaci cause systemic infections. Recent data for Chlamydophila pneumoniae in amphibians suggests that it may eventually be found to be as promiscuous as Chlamydophila psittaci. There is also increasing evidence that some chlamydiae reside in amoebae and may be widely distributed in the soil and water, certainly a confounding element in the analysis (Fritsche et al., 1998; Horn et al., 2000). 


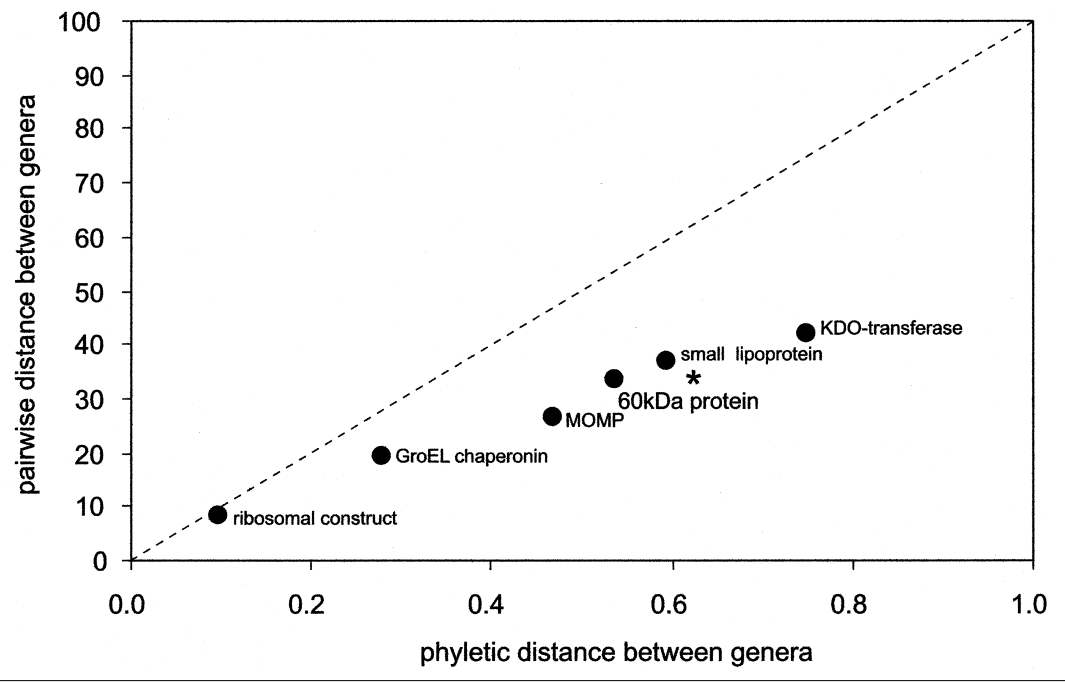

Fig. 6. Variation in rates of evolution. Contrasts of the pairwise and phyletic genetic distances between the two genera show variation in the relative rate of evolution of rRNA and five coding genes. The percentage pairwise distance is the percentage of non-gapped nucleotide positions that differed between sequences. The phyletic distance is the ML estimate of the genetic distance between sequences, in nucleotide substitutions per site. The diagonal line indicates the predicted plot, had phyletic and pairwise distances been equal. The asterisk on the MOMP plot shows the between-genus contrast, had the variable segments been included.

Our results suggest that closely related Chlamydiaceae species are no more likely to share a host, or any of the other virulence traits listed in Table 1, than are distantly related chlamydial species. One explanation that has been offered for such observations is possible lateral transfer of genes encoding virulence traits. There is evidence for LGT between the lymphogranuloma venereum and trachoma biovars of Chlamydia trachomatis, as can be seen by comparing the placement of L1, L2 and L3 in the MOMP tree (Fig. 2) with their placement in the cysteine-rich $60 \mathrm{kDa}$ protein tree (Fig. 5). However, we found no evidence for LGT above the species level in any gene. Thus, LGT would only explain the lack of congruence between host and pathogen phylogenies if it occurred at genetic loci other than those studied here. LGT above the species level in chlamydiae does exist, as is apparent from the SnLSU.1 intron in Simkania negevensis 23S rRNA (Everett et al., 1999c). Transfer of this intron, which is most closely related to large ribosomal subunit introns in chloroplasts and mitochondria of algae and in mitochondria of amoebae, could have occurred via an RNA intermediate (Belfort $\&$ Perlman, 1995). However, the conditions required for one chlamydial species to take up DNA from another seem fairly prohibitive, requiring transport across one, two or three membranes. DNA transfer could occur only by a host cell being infected by both species, or by the host cell first taking up DNA from one species (e.g. by pinocytosis) while it was concurrently infected with a second, or by viral (phage) transfer of genomic sequences. Chlamydiaphages have been identified in Chlamydophila psittaci, Chlamydophila abortus, Chlamydophila caviae and Chlamydophila pneumoniae species (Bavoil et al., 2000; Everson et al., 2000), but these do not have incorporated genomic sequences. Researchers who have attempted to co-infect host cells with two different species of chlamydiae found that intracellular inclusions did not merge (Matsumoto et al., 1991), and hence there was no common vacuole in which DNA exchange could occur. Some evidence suggests that gene transfer can occur within amoebae, but experimental co-infection of amoebae with different species of chlamydiae has not been attempted, to our knowledge.

An alternative explanation to LGT and co-evolution that explains the disjunct phylogenetic distribution of host specificity is that considerable adaptation occurs in chlamydiae which successfully occupy new niches (host or host tissue), and that this has led to species formation. The virulence phenotype of the new species might then bear little similarity to those of the ancestors or nearest relatives. This is the same conclusion drawn by Fitch et al. (1993), who noted that the picture that resulted from their study, which was similar to ours but used only MOMP, the $60 \mathrm{kDa}$ protein, and a limited collection of virulence traits, is more one of pathogen versatility than coevolutionary constraint'.

\section{Differences between the two genera}

While there is no single virulence trait that distinguishes the two chlamydial genera and the processes driving the initial split are unknown, there is nonetheless a clear genetic separation of the genera. The monophyly of the two genera is supported by all eight genes that have been studied, as shown in our results and in those of previous studies (Everett \& Andersen, 1997; Everett et al., 1999a; Fitch et al., 1993; Herrmann et al., 2000; Kaltenboeck et al., 1993; Pudjiatmoko et al., 1997; Takahashi et al., 1997; Tanner, 1999; Zhang et al., 1993). Data suggest that these genera also differ in chromosomal size and structure (Everett et al., 1999a; Myers et al., 2000; Read et al., 2000). In addition, DNA-DNA hybridization differences are so large that a case could be made for four genera rather than two (Everett et al., 1999a).

Despite these genetic differences, the only known 
biochemical marker that separates the genera is glycogen particles, which can be detected only in Chlamydia trachomatis, Chlamydia suis and Chlamydia muridarum (Moulder et al., 1984; Rogers et al., 1996; Rogers \& Andersen, 1996). In over 60 years of research, reliable biological markers that fulfil the plus/minus criteria of numerical classification methods have not been found for Chlamydiaceae species or genera. Thus, our ability to discern the evolutionary processes behind their divergence is limited to genetic data. One feature that does emerge from these results is that the genus Chlamydia, with its many serotypes and nearly a dozen genetically distinct isolates of Chlamydia suis, is less genetically diverse than Chlamydophila and appears to be less variable with respect to host range. This may well be an artifact of sampling, as until recently it was believed that humans were the almost exclusive host to this lineage. The prevalence of Chlamydia in swine is disturbing and suggestive of potential health risks to humans. Why Chlamydia suis, Chlamydia trachomatis and Chlamydia muridarum should have a common ancestry is not obvious, based on their apparent host specificities. However, swine, birds and humans exchange zoonotic viruses that play clear roles in influenza evolution (reviewed by Scholtissek, 1995).

\section{Future directions}

Thus far, characterization of the Chlamydiaceae has been primarily confined to humans, food animals and companion animals. With improved identification and characterization of chlamydiae and specific targeting using PCR and other DNA-based assays, a wider host range can be tested for the presence of these pathogens (e.g. Everett \& Andersen, 1997; Everett et al., $1999 \mathrm{a}, \mathrm{b})$. At the present time there is genetic evidence for over 98 new lineages of chlamydia-like bacteria (Ossewaarde \& Meijer, 1999; Meijer et al., 2000). There is morphological evidence for chlamydia-like bacteria in alligators, bivalves, chameleons and fish (Cajaraville \& Angulo, 1991; Groff et al., 1996; Homer et al., 1994; Huchzermeyer, 1997; Jacobson \& Telford, 1990; Szakolczai et al., 1999). Further study will show whether traits such as species specificity are artifacts resulting from difficulty in laboratory isolation, from test specificity, or from limitation of studies to particular hosts or diseases. Insight into the evolution of virulence and pathogenesis of these species will help us plan strategies for countering their infectivity.

This dataset provided an unusual opportunity to examine the parallel evolution of functionally distinct and evolutionarily important genes within a genetically diverse lineage. Understanding the evolutionary history of these genes is the first step toward advanced molecular evolution studies which will examine factors affecting relative rates of evolution, identify amino acid substitutions that alter protein structure or function, characterize covariation between sequence positions, and seek out evidence of positive selection on individual codons (Bush et al., 1999a, b).

\section{ACKNOWLEDGEMENTS}

We thank Walter M. Fitch for assistance with some of the sequence alignments, Wendy A. Hambly for sequence analyses, James W. Moulder and Arthur A. Andersen for comments on the manuscript, and Arthur A. Andersen for his support.

\section{REFERENCES}

Amin, J. D. \& Wilsmore, A. J. (1995). Studies on the early phase of the pathogenesis of ovine enzootic abortion in the non-pregnant ewe. Br Vet $J$ 151, 141-155.

Andersen, A. A. (1991). Serotyping of Chlamydia psittaci isolates using serovar-specific monoclonal antibodies with the microimmunofluorescence test. J Clin Microbiol 29, 707-711.

Baehr, W., Zhang, Y. X., Joseph, T., Su, H., Nano, F. E., Everett, K. D. E. \& Caldwell, H. D. (1988). Mapping antigenic domains expressed by Chlamydia trachomatis major outer-membrane protein genes. Proc Natl Acad Sci US A 8, 4000-4004.

Balin, B. J., Gerard, H. C., Arking, E. J., Appelt, D. M., Branigan, P. J., Abrams, J. T., Whittum-Hudson, J. A. \& Hudson, A. P. (1998). Identification and localization of Chlamydia pneumoniae in the Alzheimer's brain. Med Microbiol Immunol 187, 23-42.

Batta, M. K., Asrani, R. K., Katoch, R. C., Sharma, M. \& Joshi, V. B. (1999). Experimental studies of chlamydiosis in Japanese quails. Zentbl Bakteriol 289, 47-52.

Bavoil, P. M., Hsia, R.-C., Brunham, B., Fraser, C. M. \& Read, T. D. (2000). Chlamydia psittaci GPIC and Chlamydia pneumoniae are infected by virtually identical bacteriophages. In Proceedings of the Fourth Meeting of the European Society for Chlamydia Research, p. 23. Edited by P. Saikku. Bologna: Editrice Esculapio.

Belfort, M. \& Perlman, P. S. (1995). Mechanisms of intron mobility. J Biol Cem 270, 30237-30240.

Berger, L., Volp, K., Mathews, S., Speare, R. \& Timms, P. (1999). Chlamydia pneumoniae in a free-ranging giant barred frog (Mixophyes iteratus) from Australia. J Clin Microbiol 37, 2378-2380.

Branigan, P. J., Gerard, H. C., Hudson, A. P., Schumacher, H. R., Jr $\&$ Pando, J. (1996). Comparison of synovial tissue and synovial fluid as the source of nucleic acids for detection of Chlamydia trachomatis by polymerase chain reaction. Arthritis Rheum 39, 1740-1746.

Brunham, R., Yang, C. L., Maclean, I., Kimani, J., Maitha, G. \& Plummer, F. (1994). Chlamydia trachomatis from individuals in a sexually transmitted disease core group exhibit frequent sequence variation in the major outer-membrane protein (omp1) gene. J Clin Invest 94, 458-463.

Bush, R. M., Bender, C. A., Subbarao, K., Cox, N. J. \& Fitch, W. M. (1999a). Predicting the evolution of human influenza A. Science 286, 1921-1925.

Bush, R. M., Fitch, W. M., Bender, C. A. \& Cox, N. J. (1999b). Positive selection on the $\mathrm{H} 3$ haemagglutinin gene of human influenza virus A. Mol Biol Evol 16, 1457-1465.

Cajaraville, M. P. \& Angulo, E. (1991). Chlamydia-like organisms in digestive and duct cells of mussels from the Basque coast. $J$ Invertebr Pathol 58, 381-386.

Campbell, L. A., Kuo, C. C. \& Grayston, J. T. (1998). Chlamydia pneumoniae and cardiovascular disease. Emerg Infect Dis $\mathbf{4}$, 571-579.

Carrasco, L., Segales, J., Bautista, M. J., Gomez-Villamandos, J. C., Rosell, C., Ruiz-Villamor, E. \& Sierra, M. A. (2000). Intestinal 
chlamydial infection concurrent with postweaning multisystemic wasting syndrome in pigs. Vet $\operatorname{Rec} 146,21-23$.

Carter, M. W., al-Mahdawi, S. A. H., Giles, I. G., Treharne, J. D., Ward, M. E. \& Clarke, I. N. (1991). Nucleotide sequence and taxonomic value of the major outer-membrane protein gene of Chlamydia pneumoniae IOL-207. J Gen Microbiol 137, 465-475.

CDC (Centers for Disease Control and Prevention) (1998). Compendium of measures to control Chlamydia psittaci infection among humans (psittacosis) and pet birds (avian chlamydiosis). Morb Mortal Wkly Rep 47(RR-10), 1-9.

Chae, C., Cheon, D. S., Kwon, D., Kim, O., Kim, B., Suh, J., Rogers, D. G., Everett, K. D. E. \& Andersen, A. A. (1999). In situ hybridization for the detection and localization of swine Chlamydia trachomatis. Vet Pathol 36, 133-137.

Clark, M. A., Moran, N. A. \& Baumann, P. (1999). Sequence evolution in bacterial endosymbionts having extreme base compositions. Mol Biol Evol 16, 1586-1598.

Clarkson, M. J. \& Philips, H. L. (1997). Isolation of faecal Chlamydia from sheep in Britain and their characterization by cultural properties. Vet $J$ 153, 307-310.

Cotter, T. W., Ramsey, K. H., Miranpuri, G. S., Poulsen, C. E. \& Byrne, G. I. (1997). Dissemination of Chlamydia trachomatis chronic genital tract infection in gamma interferon gene knockout mice. Infect Immun 65, 2145-2152.

Cox, H. U., Hoyt, P. G., Poston, R. P., Snider, T. G. 3rd, Lemarchand, T. X. \& O'Reilly, K. L. (1998). Isolation of an avian serovar of Chlamydia psittaci from a case of bovine abortion. $J$ Vet Diagn Invest 10, 280-282.

Denamur, E., Sayada, C., Souriau, A., Orfila, J., Rodolakis, A. \& Elion, J. (1991). Restriction pattern of the major outer-membrane protein gene provides evidence for a homogeneous invasive group among ruminant isolates of Chlamydia psittaci, J Gen Microbiol 137, 2525-2530.

Doolittle, W. F. (1999). Phylogenetic classification and the universal tree. Science 284, 2124-2128.

Everett, K. D. E. \& Andersen, A. A. (1997). The ribosomal intergenic spacer and domain I of the $23 \mathrm{~S}$ rRNA gene are phylogenetic markers for Chlamydia spp. Int J Syst Bacteriol 47, 461-473.

Everett, K. D. E., Bush, R. M. \& Andersen, A. A. (1999a). Emended description of the order Chlamydiales, proposal of Parachlamydiaceae fam. nov. and Simkaniaceae fam. nov., each containing one monotypic genus, revised taxonomy of the family Chlamydiaceae with description of five new species, and standards for the identification of organisms. Int J Syst Bacteriol 49, 415-440.

Everett, K. D. E., Hornung, L. J. \& Andersen, A. A. (1999b). Rapid detection of the Chlamydiaceae and other families in the order Chlamydiales: three PCR tests. J Clin Microbiol 37, 575-580.

Everett, K. D. E., Kahane, S., Bush, R. M. \& Friedman, M. G. (1999c). An unspliced group I intron in 23S rRNA links Chlamydiales, chloroplasts, and mitochondria. J Bacteriol 181, 4734-4740.

Everson, J. S., Liu, B. L., Vretou, E., Glannikopoulou, P., Lambden, P. R. \& Clarke, I. N. (2000). Molecular characterization of a bacteriophage (Chp2) from C. psittaci. In Proceedings of the Fourth Meeting of the European Society for Chlamydia Research, p. 26. Edited by P. Saikku. Bologna: Editrice Esculapio.

Felsenstein, J. (1978). Cases in which parsimony and compatibility methods will be positively misleading. Syst Zool 27, $401-410$.
Fitch, W. M., Peterson, E. M. \& de la Maza, L. M. (1993). Phylogenetic analysis of the outer-membrane-protein genes of Chlamydiae, and its implication for vaccine development. $\mathrm{Mol}$ Biol Evol 10, 892-913.

Forsey, T. \& Darougar, S. (1984). Acute conjunctivitis caused by an atypical Chlamydia strain: Chlamydia IOL 207. $\mathrm{Br} J$ Ophthalmol 68, 409-411.

Fox, J. G., Stills, H. F., Paster, B. J., Dewhirst, F. E., Yan, Palley, L. \& Prostak, K. (1993). Antigenic specificity and morphologic characteristics of Chlamydia trachomatis, strain SFPD, isolated from hamsters with proliferative ileitis. Lab Anim Sci 43, 405-410.

Fox, J. G., Dewhirst, F. E., Fraser, G. J., Paster, B. J., Shames, B. \& Murphy, J. C. (1994). Intracellular Campylobacter-like organism from ferrets and hamsters with proliferative bowel disease is a Desulfovibrio sp. J Clin Microbiol 32, 1229-1237.

Fritsche, T. R., Sobek, D. \& Gautom, R. K. (1998). Enhancement of in vitro cytopathogenicity by Acanthamoeba spp. following acquisition of bacterial endosymbionts. FEMS Microbiol Lett 166, 231-236.

Gaillard, E. T., Hargis, A. M., Prieur, D. J., Evermann, J. F. \& Dhillon, A. S. (1984). Pathogenesis of feline gastric Chlamydia infection. Am J Vet Res 45, 2314-2321.

Gerard, H. C., Branigan, P. J., Schumacher, H. R., Jr \& Hudson, A. P. (1998). Synovial Chlamydia trachomatis in patients with reactive arthritis/Reiter's syndrome are viable but show aberrant gene expression. J Rheumatol 25, 734-742.

Glassick, T., Giffard, P. \& Timms, P. (1996). Outer-membrane protein 2 gene sequences indicate that Chlamydia pecorum and Chlamydia pneumoniae cause infections in koalas. Syst Appl Microbiol 19, 457-464.

Gordon, F. B., Weiss, E., Quan, A. L. \& Dressler, H. R. (1966). Observations on guinea pig inclusion conjunctivitis agent. $J$ Infect Dis 116, 203-207.

Grimes, J. E. (1985). Enigmatic psittacine chlamydiosis: results of serotesting and isolation attempts, 1978 through 1983, and considerations for the future. J Am Vet Med Assoc 186, 1075-1079.

Groff, J. M., LaPatra, S. E., Munn, R. J., Anderson, M. L. \& Osburn, B. I. (1996). Epitheliocystis infection in cultured white sturgeon (Acipenser transmontanus): antigenic and ultrastructural similarities of the causative agent to the chlamydiae. $J$ Vet Diagn Invest 8, 172-180.

Gupta, R. S. (1998). Protein phylogenies and signature sequences: a reappraisal of evolutionary relationships among archaebacteria, eubacteria, and eukaryotes. Microbiol Mol Biol Rev 62, 1435-1491.

Guscetti, F., Schiller, I., Sydler, T., Corboz, L. \& Pospischil, A. (1998). Experimental Chlamydia psittaci serotype 1 enteric infection in gnotobiotic piglets: histopathological, immunohistochemical and microbiological findings. Vet Microbiol 62, 251-263.

Haag, J., OhUigin, C. \& Overath, P. (1998). The molecular phylogeny of trypanosomes: evidence for an early divergence of the Salivaria. Mol Biochem Parasitol 91, 37-49.

Hatch, T. P. (1996). Disulfide cross-linked envelope proteins: the functional equivalent of peptidoglycan in chlamydiae? $J$ Bacteriol 178, 1-5.

Hayes, L. J., Yearsley, P., Treharne, J. D., Ballard, R. A., Fehler, G. H. \& Ward, M. E. (1994). Evidence for naturally occurring recombination in the gene encoding the major outer-membrane 
protein of lymphogranuloma venereum isolates of Chlamydia trachomatis. Infect Immun 62, 5659-5663.

Hemsley, S. \& Canfield, P. J. (1996). Proctitis associated with chlamydial infection in a koala. Aust Vet J 74, 148-150.

Hemsley, S. \& Canfield, P. J. (1997). Histopathological and immunohistochemical investigation of naturally occurring chlamydial conjunctivitis and urogenital inflammation in koalas (Phascolarctos cinereus). J Comp Pathol 116, 273-290.

Herring, A. J. (1993). Typing Chlamydia psittaci-a review of methods and recent findings. Br Vet $J$ 149, 455-475.

Herrmann, B., Pettersson, B., Everett, K. D. E., Mikkelsen, N. E. \& Kirsebom, L. A. (2000). Characterization of the $\operatorname{rnpB}$ gene and RNase P RNA in the order Chlamydiales. Int J Syst Evol Microbiol 50, 149-158.

Hildebrandt, P. K. (1982). Rickettsial and chlamydial diseases. In The Mouse in Biomedical Research, vol. 2, Diseases, pp. 99-107. Edited by H. L. Foster, J. D. Small \& J. G. Fox. New York: Academic Press.

Homer, B. L., Jacobson, E. R., Schumacher, J. \& Scherba, G. (1994). Chlamydiosis in mariculture-reared green sea turtles (Chelonia mydas). Vet Pathol 31, 1-7.

Horn, M., Wagner, M., Müller, K.-D., Schmid, E. N., Fritsche, T. R., Schleifer, K.-H. \& Michel, R. (2000). Neochlamydia hartmannellae gen. nov., sp. nov. (Parachlamydiaceae), an endoparasite of the amoeba Hartmannella vermiformis. Microbiology 146, 1231-1239.

Huchzermeyer, F. W. (1997). Public health risks of ostrich and crocodile meat. Rev Sci Technol 16, 599-604.

Jackson, L. A., Campbell, L. A., Schmidt, R. A., Kuo, C.-C., Cappuccio, A. L., Lee, M. J. \& Grayston, J. T. (1997). Specificity of detection of Chlamydia pneumoniae in cardiovascular atheroma: evaluation of the innocent bystander hypothesis. $\mathrm{Am} \mathrm{J}$ Pathol 150, 1785-1790.

Jacobson, E. R. \& Telford, S. R. (1990). Chlamydial and poxvirus infections of circulating monocytes of a flap-necked chameleon (Chamaeleo dilepis). $J$ Wildl Dis 26, 572-577.

Jones, G. E., Donn, A., Machell, J., Biolatti, B. \& Appino, S. (1998) Experimental infections of the genital tract of cattle with Chlamydia psittaci and Chlamydia pecorum. In Proceedings of the Ninth International Symposium on Human Chlamydia Infections, pp. 446-449. Edited by R. S. Stephens, G. I. Byrne, G. Christiansen, I. N. Clarke, J. T. Grayston, R. G. Rank, G. L. Ridgway, P. Saikku, J. Schachter \& W. E. Stamm. San Francisco: International Chlamydia Symposium.

Jorgensen, D. M. (1997). Gestational psittacosis in a Montana sheep rancher. Emerg Infect Dis 3, 191-194.

Kalman, S., Mitchell, W., Marathe, R., Lammel, C., Fan, J., Hyman, R. W., Olinger, L., Grimwood, J., Davis, R. W. \& Stephens, R. S. (1999). Comparative genomes of Chlamydia pneumoniae and $C$. trachomatis. Nat Genet 21, 385-389.

Kaltenboeck, B., Kousoulas, K. G. \& Storz, J. (1993). Structures of and allelic diversity and relationships among the major outermembrane protein $($ omp $A)$ genes of the four Chlamydia species. $J$ Bacteriol 175, 487-502.

Kik, M. J. L., van der Hage, M. H. \& Greydanus-van der Putten, S. W. M. (1997). Chlamydiosis in a fishing cat (Felis viverrina). $J$ Zoo Wildl Med 28, 212-214.

Koehler, L., Nettelnbreker, E., Hudson, A. P., Ott, N., Gerard, H. C., Branigan, P. J., Schumacher, H. R., Drommer, W. \& Zeidler, H. (1997). Ultrastructural and molecular analyses of the persistence of Chlamydia trachomatis (serovar $\mathrm{K}$ ) in human monocytes. Microb Pathog 22, 133-142.
Kosma, P. (1999). Chlamydial lipopolysaccharide. Biochim Biophys Acta 1455, 387-402.

LaVerda, D., Kalayoglu, M. V. \& Byrne, G. I. (1999). Chlamydial heat-shock proteins and disease pathology: new paradigms for old problems? Infect Dis Obstet Gynecol 7, 64-71.

Lindsey, J. R., Cassell, G. H. \& Davidson, M. K. (1982). Mycoplasmal and other bacterial diseases of the respiratory system. In The Mouse in Biomedical Research, vol. 2, Diseases, pp. 21-41. Edited by H. L. Foster, J. D. Small \& J. G. Fox. New York: Academic Press.

Lipman, N. S., Yan, L. L. \& Murphy, J. C. (1994). Probable transmission of Chlamydia psittaci from a macaw to a cat. $\mathrm{J} \mathrm{Am}$ Vet Med Assoc 204, 1479-1480.

McChesney, S. L., England, J. J. \& McChesney, A. E. (1982). Chlamydia psittaci induced pneumonia in a horse. Cornell Vet 72, 92-97.

Mair, T. S. \& Wills, J. M. (1992). Chlamydia psittaci infection in horses: results of a prevalence survey and experimental challenge. Vet Rec 130, 417-419.

Matsumoto, A., Bessho, H., Uehira, K. \& Suda, T. (1991). Morphological studies of the association of mitochondria with chlamydial inclusions and the fusion of chlamydial inclusions. $J$ Electron Microsc (Tokyo) 40, 356-363.

May, S. W., Kelling, C. L., Sabara, M. \& Sandbulte, J. (1996). Virulence of feline Chlamydia psittaci in mice is not a function of the major outer-membrane protein. Vet Microbiol 53, 355-368.

Meijer, A., Roholl, P. J. M. \& Ossewaarde, J. M. (2000). Use of the broad range PCR assay for the identification and classification of bacteria in the order Chlamydiales. In Proceedings of the Fourth Meeting of the European Society for Chlamydia Research, p. 9. Edited by P. Saikku. Bologna: Editrice Esculapio.

Moazed, T. C., Kuo, C.-C., Grayston, J. T. \& Campbell, L. A. (1998). Evidence of systemic dissemination of Chlamydia pneumoniae via macrophages in the mouse. J Infect Dis 177, 1322-1325.

de la Monte, S. M. \& Hutchins, G. M. (1985). Follicular proctocolitis and neuromatous hyperplasia with lymphogranuloma venereum. Hum Pathol 16, 1025-1032.

Moulder, J. W., Hatch, T. P., Kuo, C.-C., Schachter, J. \& Storz, J. (1984). Genus Chlamydia. In Bergey's Manual of Systematic Bacteriology, vol. 1, pp. 729-739. Edited by N. R. Krieg. Baltimore: Williams \& Wilkins.

Murray, E. S. (1964). Guinea pig inclusion conjunctivitis virus. I. Isolation and identification as a member of the psittacosislymphogranuloma-trachoma group. J Infect Dis 114, 1-12.

Myers, G., Brettin, T., Brettin, M., Leach, R. \& Lu, H. (2000). Los Alamos National Laboratory Bioscience Division. STD Sequence Databases. http://www.stdgen.lanl.gov/

Nietfeld, J. C., Leslie-Steen, P., Zeman, D. H. \& Nelson, D. (1997). Prevalence of intestinal Chlamydia infection in pigs in the midwest, as determined by immunoperoxidase staining. Am J Vet Res 58, 260-264.

Nigg, C. (1942). Unidentified virus which produces pneumonia and systemic infection in mice. Science 95, 49-50.

Ossewaarde, J. M. \& Meijer, A. (1999). Molecular evidence for the existence of additional members of the order Chlamydiales. Microbiology 145, 411-417.

Page, L. A. (1966). Interspecies transfer of psittacosis-LGVtrachoma agents: pathogenicity of two avian and two mammalian strains for eight species of birds and mammals. Am J Vet Res 27, 397-407. 
Page, L. A. (1967). Comparison of "pathotypes" among Chlamydia (psittacosis) strains recovered from diseased birds and mammals. Bull Wildl Dis Assoc 3, 166-175.

Palys, T., Nakamura, L. K. \& Cohan, F. M. (1997). Discovery and classification of ecological diversity in the bacterial world: the role of DNA sequence data. Int J Syst Bacteriol 47, 1145-1156.

Patterson, T. L. \& Rank, R. G. (1996). Immunity to reinfection and immunization of male guinea pigs against urethral infection with the agent of guinea pig inclusion conjunctivitis. Sex Transm Dis 23, 145-150.

Perry, L. L. \& Hughes, S. (1999). Chlamydial colonization of multiple mucosae following infection by any mucosal route, Infect Immun 67, 3686-3689.

Pettersson, B., Andersson, A., Leitner, T., Olsvik, O., Uhlen, M., Storey, C. \& Black, C. M. (1997). Evolutionary relationships among members of the genus Chlamydia based on 16S rDNA analysis. J Bacteriol 179, 4195-4205.

Philips, H. L. \& Clarkson, M. J. (1998). Experimental infection of pregnant ewes with Chlamydia pecorum. Infect Immun 66, 2818-2821.

Prain, C. J. \& Pearce, J. H. (1989). Ultrastructural studies on the intracellular fate of Chlamydia psittaci (strain guinea pig inclusion conjunctivitis) and Chlamydia trachomatis (strain lymphogranuloma venereum 434): modulation of intracellular events and relationship with endocytic mechanism. $J$ Gen Microbiol 135, 2107-2123.

Pudjiatmoko, Fukushi, H., Ochiai, Y., Yamaguchi, T. \& Hirai, K. (1997). Phylogenetic analysis of the genus Chlamydia based on 16S rRNA gene sequences. Int J Syst Bacteriol 47, 425-431.

Rank, R. G. \& Sanders, M. M. (1992). Pathogenesis of endometritis and salpingitis in a guinea pig model of chlamydial genital infection. Am J Pathol 140, 927-936.

Rank, R. G., White, H. J., Soloff, B. L. \& Barron, A. L. (1981). Cystitis associated with Chlamydia infection of the genital tract in male guinea pigs. Sex Transm Dis 8, 203-210.

Rank, R. G., Hough, A. J., Jr, Jacobs, R. F., Cohen, C. \& Barron, A. L. (1985). Chlamydia pneumonitis induced in newborn guinea pigs. Infect Immun 48, 153-158.

Rank, R. G., Sanders, M. M. \& Kidd, A. T. (1993). Influence of the estrous cycle on the development of upper genital tract pathology as a result of chlamydial infection in the guinea pig model of pelvic inflammatory disease. Am J Pathol 142, 1291-1296.

Read, T. D., Brunham, R. C., Shen, C. \& 22 other authors (2000). Genome sequences of Chlamydia trachomatis MoPn and Chlamydia pneumoniae AR39. Nucleic Acids Res 28, 1397-1406.

Reed, K. D., Ruth, G. R., Meyer, J. A. \& Shukla, S. K. (2000). Chlamydia pneumoniae infection in a breeding colony of African clawed frogs (Xenopus tropicalis). Emerg Infect Dis 6, 196-199.

Rodolakis, A. \& Souriau, A. (1992). Restriction endonuclease analysis of DNA from ruminant Chlamydia psittaci and its relation to mouse virulence. Vet Microbiol 31, 263-271.

Rodolakis, A., Bernard, F. \& Lantier, F. (1989). Mouse models for evaluation of virulence of Chlamydia psittaci isolated from ruminants. Res Vet Sci 46, 34-39.

Rogers, D. G. \& Andersen, A. A. (1996). Intestinal lesions caused by two swine chlamydial isolates in gnotobiotic pigs. $J \mathrm{Vet}$ Diagn Invest 8, 433-440.

Rogers, D. G., Andersen, A. A. \& Hunsaker, B. D. (1996). Lung and nasal lesions caused by a swine chlamydial isolate in gnotobiotic pigs. $J$ Vet Diagn Invest 8, 45-55.
Rosenblum, B. B., Lee, L. G., Spurgeon, S. L., Khan, S. H., Menchen, S. M., Heiner, C. R. \& Chen, S. M. (1997). New dyelabelled terminators for improved DNA sequencing patterns. Nucleic Acids Res 25, 4500-4504.

Rurangirwa, F. R., Dilbeck, P. M., Crawford, T. B., McGuire, T. C. \& McElwain, T. F. (1999). Analysis of the $16 \mathrm{~S}$ rRNA gene of microorganism WSU 86-1044 from an aborted bovine foetus reveals that it is a member of the order Chlamydiales: proposal of Waddliaceae fam. nov., Waddlia chondrophila gen. nov., sp. nov. Int J Syst Bacteriol 49, 577-581.

Saikku, P., Laitinen, K. \& Leinonen, M. (1998). Animal models for Chlamydia pneumoniae infection. Atherosclerosis 140 (suppl. 1), S17-19.

Schachter, J. (1999). Infection and disease epidemiology. In Chlamydia, Intracellular Biology, Pathogenesis \& Immunity, pp. 139-169. Edited by R. S. Stephens. Washington, DC: American Society for Microbiology Press.

Schachter, J., Ostler, H. B. \& Meyer, K. F. (1969). Human infection with the agent of feline pneumonitis. Lancet 1, 1063-1065.

Scholtissek, C. (1995). Molecular evolution of influenza viruses. Virus Genes 11, 209-215.

Sharma, M., Rogers, D. R. \& Andersen, A. A. (1999). Prevalence of Chlamydia trachomatis infection in swine. Abstr Gen Meet Am Soc Microbiol 99, 174.

Stagg, A. J., Hughes, R. A., Keat, A. C. S., Elsley, W. A. J. \& Knight, S. C. (1996). Antigen-presenting cells but not lymphocytes in the joint may indicate the cause of reactive arthritis. Br J Rheumatol 35, 1082-1090.

Stephens, R. S. (editor) (1999). Chlamydia, Intracellular Biology, Pathogenesis, and Immunity. Washington DC: American Society for Microbiology Press.

Stephens, R. S., Sanchez-Pescador, R., Wagar, E. A., Inouye, C. \& Urdea, M. S. J. (1987). Diversity of Chlamydia trachomatis major outer-membrane protein genes. J Bacteriol 169, 3879-3885.

Stephens, R. S., Kalman, S., Lammel, C. \& 9 other authors (1998). Genome sequence of an obligate intracellular pathogen of humans: Chlamydia trachomatis. Science 282, 754-759.

Stiller, J. W. \& Hall, B. D. (1999). Long-branch attraction and the rDNA model of early eukaryotic evolution. Mol Biol Evol 16, 1270-1279.

Storz, J., McKercher, D. G., Howarth, J. A. \& Straub, O. C. (1960). The isolation of a viral agent from epizootic bovine abortion. $J$ Am Vet Med Assoc 137, 509-514.

Storz, J., Call, J. W. \& Miner, M. L. (1963). Meningo-encephalitis in young chickens resulting from infection with an ornithosis agent. Avian Dis 7, 480-494.

Stothard, D. R., Boguslawski, G. \& Jones, R. B. (1998). Phylogenetic analysis of the Chlamydia trachomatis major outermembrane protein and examination of potential pathogenic determinants. Infect Immun 66, 3618-3625.

Strimmer, K. \& von Haeseler, A. (1996). Quartet puzzling: a maximum-likelihood method for reconstructing tree topologies, Mol Biol Evol 13, 964-969.

Swofford, D. L. (2000). PAUP*. Phylogenetic Analysis Using Parsimony (* and Other Methods). Version 4. Sunderland, MA: Sinauer Associates.

Szakolczai, J., Vetesi, F. \& Pitz, S. R. (1999). Epitheliocystis disease in cultured pacu (Piaractus mesopotamicus) in Brazil, Acta Vet Hung 47, 311-318.

Takahashi, T., Takashima, I. \& Hashimoto, N. (1988a). Shedding 
and transmission of Chlamydia psittaci in experimentally infected chickens. Avian Dis 32, 650-658.

Takahashi, T., Takashima, I. \& Hashimoto, N. (1988b). A chicken model of systemic infection with Chlamydia psittaci: comparison of the virulence among avian and mammalian strains. Nippon Juigaku Zasshi 50, 622-631.

Takahashi, T., Masuda, M., Tsuruno, T., Mori, Y., Takashima, I., Hiramune, T. \& Kikuchi, N. (1997). Phylogenetic analyses of Chlamydia psittaci strains from birds based on 16S rRNA gene sequence. J Clin Microbiol 35, 2908-2914.

Tanner, M. A., Harris, J. K. \& Pace, N. R. (1999). Molecular phylogeny of Chlamydia and relatives. In Chlamydia, Intracellular Biology, Pathogenesis \& Immunity, pp. 1-8. Edited by R. S. Stephens. Washington, DC: American Society for Microbiology Press.

TerWee, J., Sabara, M., Kokjohn, K., Sandbulte, J., Frenchick, P. \& Dreier, K. J. (1998). Characterization of the systemic disease and ocular signs induced by experimental infection with Chlamydia psittaci in cats. Vet Microbiol 59, 259-281.

Thompson, J. D., Higgins, D. G. \& Gibson, T. J. (1994). CLUSTAL $\mathrm{W}$ : improving the sensitivity of progressive multiple sequence alignment through sequence weighting, position-specific gap penalties and weight matrix choice. Nucleic Acids Res 22, 4673-4680.

Vanrompay, D., De Meurichy, W., Ducatelle, R. \& Haesebrouck, F. (1994). Pneumonia in Moorish tortoises (Testudo graeca) associated with avian serovar A Chlamydia psittaci. Vet Rec 135, 284-285.

Vanrompay, D., Mast, J., Ducatelle, R., Haesebrouck, F. \& Goddeeris, B. (1995). Chlamydia psittaci in turkeys: pathogenesis of infections in avian serovars A, B and D. Vet Microbiol 47, $245-256$

Vuillaumier, S., Kaltenboeck, B., Lecointre, G., Lehn, P. \&
Denamur, E. (1997). Phylogenetic analysis of cystic fibrosis transmembrane conductance regulator gene in mammalian species argues for the development of a rabbit model for cystic fibrosis. Mol Biol Evol 14, 372-380.

Ward, M. E. (1995). The immunobiology and immunopathology of chlamydial infections. APMIS 103, 769-796.

Wardrop, S., Fowler, A., O'Callaghan, P., Giffard, P. \& Timms, P. (1999). Characterization of the koala biovar of Chlamydia pneumoniae at four gene loci-omp $A$ VD4, ompB, 16S rRNA, groESL spacer region. Syst Appl Microbiol 22, 22-27.

Wilkinson, N. Z., Kingsley, G. H., Sieper, J., Braun, J. \& Ward, M. E. (1998). Lack of correlation between the detection of Chlamydia trachomatis DNA in synovial fluid from patients with a range of rheumatic diseases and the presence of an antichlamydial immune response. Arthritis Rheum 41, 845-854.

Wolf, Y. I., Aravind, L. \& Koonin, E. V. (1999). Rickettsiae and Chlamydiae: evidence of horizontal gene transfer and gene exchange. Trends Genet 15, 173-175.

Yang, Y. S., Kuo, C.-C. \& Chen, W. J. (1983). Reactivation of Chlamydia trachomatis lung infection in mice by cortisone. Infect Immun 39, 655-658.

Zhang, Y. X., Morrison, S. G., Caldwell, H. D. \& Baehr, W. (1989). Cloning and sequence analysis of the major outer-membrane protein genes of two Chlamydia psittaci strains. Infect Immun 57, 1621-1625.

Zhang, Y. X., Fox, J. G., Ho, Y., Zhang, L., Stills, H. F., Jr \& Smith, T. F. (1993). Comparison of the major outer-membrane protein (MOMP) gene of mouse pneumonitis (MoPn) and hamster SFPD strains of Chlamydia trachomatis with other Chlamydia strains. Mol Biol Evol 10, 1327-1342.

Zollner, B., Feucht, H. H., Koch, H., Iske, L., Oehler, G., Stellbrink, H. J. \& Laufs, R. (1993). Isolation of Chlamydia trachomatis from the lower digestive tract. Infection 21, 318-320. 